Atmos. Chem. Phys., 19, 15217-15234, 2019

https://doi.org/10.5194/acp-19-15217-2019

(C) Author(s) 2019. This work is distributed under

the Creative Commons Attribution 4.0 License.

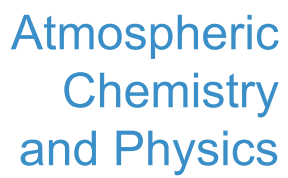

(c) (P)

\title{
Remote biomass burning dominates southern West African air pollution during the monsoon
}

\author{
Sophie L. Haslett ${ }^{1}$,, Jonathan W. Taylor ${ }^{1}$, Mathew Evans ${ }^{2,3}$, Eleanor Morris ${ }^{2}$, Bernhard Vogel ${ }^{4}$, Alima Dajuma ${ }^{4,5}$, \\ Joel Brito $^{6}$, Anneke M. Batenburg ${ }^{7}$, Stephan Borrmann ${ }^{7}$, Johannes Schneider ${ }^{7}$, Christiane Schulz ${ }^{7}$, \\ Cyrielle Denjean $^{8}$, Thierry Bourrianne ${ }^{8}$, Peter Knippertz ${ }^{4}$, Régis Dupuy ${ }^{9}$, Alfons Schwarzenböck ${ }^{9}$, Daniel Sauer $^{10}$, \\ Cyrille Flamant $^{11}$, James Dorsey ${ }^{1,12}$, Ian Crawford ${ }^{1}$, and Hugh Coe ${ }^{1}$ \\ ${ }^{1}$ School of Earth and Environmental Sciences, University of Manchester, Manchester, UK \\ ${ }^{2}$ Wolfson Atmospheric Chemistry Laboratories, Department of Chemistry, University of York, York, UK \\ ${ }^{3}$ National Centre for Atmospheric Science, University of York, York, UK \\ ${ }^{4}$ Institute of Meteorology and Climate Research, Karlsruhe Institute of Technology, Karlsruhe, Germany \\ ${ }^{5}$ L'Université Félix Houphoët-Boigny, Abidjan 01, Côte d'Ivoire \\ ${ }^{6}$ Laboratory for Meteorological Physics (LaMP), University Blaise Pascal, Aubière, France \\ ${ }^{7}$ Particle Chemistry Department, Johannes Gutenberg University Mainz/Max Planck Institute for Chemistry, \\ 55128 Mainz, Germany \\ ${ }^{8}$ CNRM, Université de Toulouse, Météo-France, CNRS, Toulouse, France \\ ${ }^{9}$ Laboratoire de Météorologie Physique, Université Clermont Auvergne, Aubière, France \\ ${ }^{10}$ Institut für Physik der Atmosphäre, Deutsches Zentrum für Luft- und Raumfahrt, Oberpfaffenhofen, Wessling, Germany \\ ${ }^{11}$ LATMOS/IPSL, Sorbonne Université, UVSQ, CNRS, Paris, France \\ ${ }^{12}$ National Centre for Atmospheric Science, University of Manchester, Manchester, UK \\ ${ }^{a}$ now at: Department of Environmental Science and Analytical Chemistry, Stockholm University, Stockholm 11418, Sweden
}

Correspondence: Hugh Coe (hugh.coe@ manchester.ac.uk)

Received: 15 January 2019 - Discussion started: 11 April 2019

Revised: 9 September 2019 - Accepted: 6 November 2019 - Published: 16 December 2019

\begin{abstract}
Vast stretches of agricultural land in southern and central Africa are burnt between June and September each year, which releases large quantities of aerosol into the atmosphere. The resulting smoke plumes are carried west over the Atlantic Ocean at altitudes between 2 and $4 \mathrm{~km}$. As only limited observational data in West Africa have existed until now, whether this pollution has an impact at lower altitudes has remained unclear. The Dynamics-aerosol-chemistry-cloud interactions in West Africa (DACCIWA) aircraft campaign took place in southern West Africa during June and July 2016, with the aim of observing gas and aerosol properties in the region in order to assess anthropogenic and other influences on the atmosphere.

Results presented here show that a significant mass of aged accumulation mode aerosol was present in the southern West African monsoon layer, over both the ocean and the continent. A median dry aerosol concentration of $6.2 \mu \mathrm{g} \mathrm{m}^{-3}$
\end{abstract}

(standard temperature and pressure, STP) was observed over the Atlantic Ocean upwind of the major cities, with an interquartile range from 5.3 to $8.0 \mu \mathrm{g} \mathrm{m}^{-3}$. This concentration increased to a median of $11.1 \mu \mathrm{g} \mathrm{m}^{-3}$ (8.6 to $15.7 \mu \mathrm{g} \mathrm{m}^{-3}$ ) in the immediate outflow from cities. In the continental air mass away from the cities, the median aerosol loading was $7.5 \mu \mathrm{g} \mathrm{m}^{-3}$ (5.9 to $10.5 \mu \mathrm{g} \mathrm{m}^{-3}$ ). The accumulation mode aerosol population over land displayed similar chemical properties to the upstream population, which implies that upstream aerosol is a significant source of aerosol pollution over the continent. The upstream aerosol is found to have most likely originated from central and southern African biomass burning. This demonstrates that biomass burning plumes are being advected northwards, after being entrained into the monsoon layer over the eastern tropical Atlantic Ocean. It is shown observationally for the first time that they contribute up to $80 \%$ to the regional aerosol loading in 
the monsoon layer over southern West Africa. Results from the COSMO-ART (Consortium for Small-scale Modeling Aerosol and Reactive Trace gases) and GEOS-Chem models support this conclusion, showing that observed aerosol concentrations over the northern Atlantic Ocean can only be reproduced when the contribution of transported biomass burning aerosol is taken into account.

As a result, the large and growing emissions from the coastal cities are overlaid on an already substantial aerosol background. Simulations using COSMO-ART show that cloud droplet number concentrations can increase by up to $27 \%$ as a result of transported biomass burning aerosol. On a regional scale this renders cloud properties and precipitation less sensitive to future increases in anthropogenic emissions. In addition, such high background loadings will lead to greater pollution exposure for the large and growing population in southern West Africa. These results emphasise the importance of including aerosol from across country borders in the development of air pollution policies and interventions in regions such as West Africa.

\section{Introduction}

West Africa is currently undergoing rapid urbanisation, population growth and industrial development. As a result of these large socioeconomic changes, anthropogenic pollution in the region tripled between 1950 and 2000 (Lamarque et al., 2010) and is expected to do so again from 2005 to 2030 (Liousse et al., 2014). Nevertheless, West African air quality is among the most poorly studied worldwide. As a result, these changes are being imposed on a largely unknown regional background (Zuidema et al., 2016; Knippertz et al., 2015).

Plumes of biomass burning pollution from further afield are known to impact the mid-troposphere above West Africa during the summer monsoon (Chatfield et al., 1998; Mari et al., 2008; Murphy et al., 2010; Reeves et al., 2010; Sauvage et al., 2005). These plumes are the result of vast quantities of agricultural land in southern and central Africa being burnt between June and September each year (Barbosa et al., 1999). The large-scale burning releases large quantities of aerosol into the atmosphere, which are carried west over the Atlantic Ocean at altitudes between 2 and $4 \mathrm{~km}$. This transport mechanism is reliant on the southern-hemispheric African easterly jet; when the jet is active, vast intrusions of biomass burning pollution can be transported across the Atlantic Ocean, in some cases as far west as South America (Mari et al., 2008). Intrusions into southern West Africa have been well documented from in situ and satellite data. To date, this phenomenon has been thought to be confined predominantly to layers between 2 and $4 \mathrm{~km}$ in altitude (Barbosa et al., 1999; Capes et al., 2008; Chatfield et al., 1998; Mari et al., 2008).
Though recent modelling studies (Deroubaix et al., 2018; Menut et al., 2018) indicate that pollution may mix further down into the boundary layer, this has remained unconfirmed due to limited in situ observations. Recent attempts to quantify the extent to which smoke over the Atlantic Ocean entrains into the boundary layer using model simulations have shown that different models can provide very different results (Das et al., 2017; Peers et al., 2016). Deroubaix et al. (2018) suggest that long-range transport of biomass burning aerosol could have contributed around $50 \%$ of $\mathrm{PM}_{2.5}$ (aerosol smaller than $2.5 \mu \mathrm{m}$ in diameter) mass in southern West Africa during the monsoon season observed by the AMMA campaign in 2006. These results make the collection and analysis of observational evidence on this matter particularly important, to confirm and quantify the presence of long-range-transported aerosol in the boundary layer.

Both near-field and remote sources of pollution are likely to have an effect on cloud properties, radiative forcing and human health in southern West Africa. During the onset of the West African Monsoon, aerosol becomes entrained into newly forming banks of monsoon clouds, so it could have a resultant effect on rainfall patterns as well as the region's response to climate change. The emergence of megacities along the southern coast means that large numbers of people will be exposed to any atmospheric pollutants that exist in the region.

Airborne measurements made during the Dynamicsaerosol-chemistry-cloud interactions in West Africa (DACCIWA) campaign (Knippertz et al., 2015; Flamant et al., 2018) in June-July 2016 provided the opportunity to map aerosol properties in southern West Africa extensively. Here, observations from the three aircraft employed during the campaign are used to examine the relative contributions of local and transported pollution towards the aerosol loading in the regional monsoon layer $(<1.9 \mathrm{~km})$ in southern West Africa. The relative contributions of regional urban emissions and aged biomass burning aerosol from central and southern Africa towards this background are assessed, using both observational evidence and simulations from the COSMO-ART (Consortium for Small-scale Modeling Aerosol and Reactive Trace gases) and GEOS-Chem models. Biomass burning aerosol advected inland from remote sources is found to be the key driver of particulate pollution in the monsoon layer over southern West Africa away from large urban centres. The effect of this influx of long-range pollution on clouds forming during the monsoon period is assessed using the COSMO-ART model.

\section{Method}

\subsection{Airborne observations}

The DACCIWA aircraft campaign took place during June and July 2016 and focused on the highly populated south- 


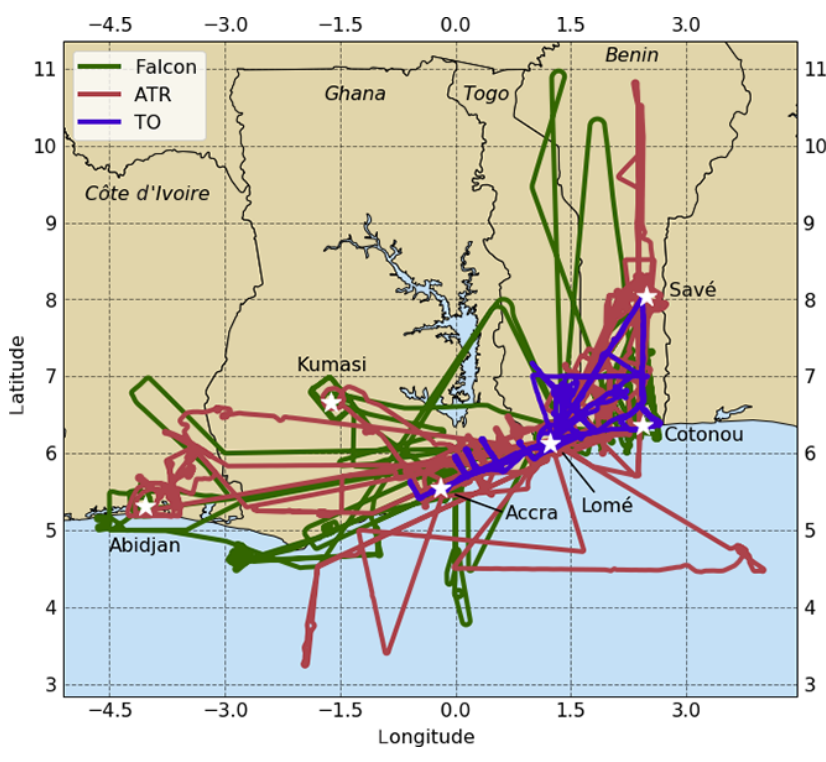

Figure 1. Map showing the flight paths of the Falcon, ATR and Twin Otter aircraft during the DACCIWA campaign.

ern coastal region of West Africa. Science flying began on 29 June and concluded on 16 July 2016. Three aircraft took part in the campaign: the German Deutsches Zentrum für Luft- und Raumfahrt (DLR) Falcon 20, the French Service des Avions Français Instrumentés pour la Recherche en Environnement (SAFIRE) ATR-42 and the British Antarctic Survey (BAS) Twin Otter. All three aircraft were based at the military airport in Lomé, Togo $\left(6.16^{\circ} \mathrm{N}, 1.25^{\circ} \mathrm{E}\right)$, though the ATR-42 flew to the Aéroport Félix Houphouët-Boigny in Abidjan, Côte d'Ivoire, twice, on 6 and 11 July. In total, 50 scientific flights were carried out, which comprised $155 \mathrm{~h}$ of scientific sorties. The DLR Falcon completed 12 scientific missions during the campaign, the ATR-42 completed 20 and the Twin Otter completed 18 (Flamant et al., 2018). The aircraft campaign took place after the monsoon onset; at this time, the bulk of the monsoon rainfall is typically north over the Sahel, with limited precipitation in southern West Africa. The measurement period in 2016 was characterised by a northward-shifted intertropical discontinuity, which likely resulted in less wet deposition than usual. This period has been described as phase 2 of the 2016 West African Monsoon (Knippertz et al., 2017).

Several flights were conducted between Lomé and the air above a ground station in Savè, Benin $\left(8.03^{\circ} \mathrm{N}, 2.48^{\circ} \mathrm{E}\right)$, around $250 \mathrm{~km}$ to the north-east, which were used to build up statistics on background aerosol concentrations and cloudaerosol interactions. Other flight patterns included city emission flights, which targeted city plumes and flights over the sea. Flight paths for all three aircraft are shown in Fig. 1.

Submicron aerosol chemical composition was measured using Aerodyne compact time-of-flight aerosol mass spectrometers (AMSs) (Drewnick et al., 2005; Canagaratna et al.,
2007), mounted on board all three aircraft. The instrument samples submicron particles from ambient air through an aerodynamic lens, which focuses the particles in the vacuum chamber into a narrow beam. The particle beam is directed onto a hot surface vaporiser $\left(\sim 600^{\circ} \mathrm{C}\right)$ where the particles are flash evaporated. The gas molecules formed are then ionised by electron ionisation, and the ions are analysed in a time-of-flight mass spectrometer. The AMS produces quantitative chemical mass loading information for organic and inorganic non-refractory submicron aerosols with a time resolution of 20-45 s. A fragmentation table (Allan et al., 2004) was used to distinguish different compounds, yielding measurements of sulfate $\left(\mathrm{SO}_{4}\right)$, nitrate $\left(\mathrm{NO}_{3}\right)$, ammonium $\left(\mathrm{NH}_{4}\right)$ and organic compounds. An average collection efficiency of 0.5 was used throughout the campaign, which is standard for ambient measurements in similar environments (Middlebrook et al., 2012). The ionisation efficiencies of the instruments were calibrated several times throughout the campaign using size-selected ammonium nitrate aerosol. A more detailed description of the ATR AMS data processing has been described by Brito et al. (2018).

Submicron aerosol size distributions were measured using a TSI scanning mobility particle sizer (SMPS) on board the ATR aircraft. This produced a size distribution of aerosol between 0.02 and $0.5 \mu \mathrm{m}$ every $90 \mathrm{~s}$. Condensation nuclei number concentrations were measured using condensation particle counters (CPCs) on board each of the three aircraft (a Brechtel Mixing CPC on the Twin Otter, modified TSI 3010 on the Falcon and TSI 3788 CPC on the ATR; lower size limits were 3,14 and $3 \mathrm{~nm}$ respectively).

In order to integrate these datasets successfully, the sensitivities of the instruments on all three platforms were compared. The transect between the coastal city of Lomé in Togo and the inland city of Savè in Benin was flown several times by each aircraft, which provided a basis for performing statistical comparisons. The median measurements of the AMS instruments on the ATR and the Twin Otter aircraft were within $20 \%$ of one another, although a larger interquartile range was observed in measurements from the ATR. The CPCs on board all three instruments showed a discrepancy in the median values of less than $10 \%$. Where applicable, measurements were corrected to standard temperature and pressure (STP).

The AMS data were compared for the take-offs and landings at Lomé airport. Despite calibration efforts, the AMS on the Falcon measured lower mass concentrations than the other two at low altitudes. This is believed to have been caused by a loss process at its inlet that affected the absolute, but not the relative, measured mass concentrations of the different compounds. Therefore, only the proportional chemical distribution and the high-altitude mass concentrations from the Falcon AMS are used here. It is indicated in the text where these data are included.

The West African Monsoon governs surface level wind patterns in southern West Africa during June and July. 
Southerlies associated with the monsoon bring air into West Africa that has been advected over the ocean for several thousand kilometres (Williams et al., 2007). The incoming air is then affected by large coastal cities before continuing inland. In order to study the influence of different sources, aerosol was analysed in three regimes: "upwind marine", "continental background" and "urban outflow". The first two include data collected above the ocean more than $20 \mathrm{~km}$ south of the shoreline and over West Africa away from immediate urban sources, respectively. This distinction provides a direct comparison between upwind air entering the region from the south and that influenced by the coastal cities, Abidjan (Côte d'Ivoire), Accra (Ghana), Lomé (Togo) or Cotonou (Benin). The urban outflow regime includes data from the centre of near-field urban plumes.

In all three cases, only aerosol below $1.9 \mathrm{~km}$ was considered. This is the height of the monsoon layer: the deep, moist layer that transports moisture into the continent from the south (Kalthoff et al., 2018). The boundary layer is the layer in direct exchange with the surface. This is typically shallow over the ocean (around $500 \mathrm{~m}$ ); when the air reaches land, however, a much deeper mixing results in the low boundary layer over ocean mixing with the air above it to deepen the boundary layer to around $1.5 \mathrm{~km}$ and to determine the concentration further inland. It is the monsoon layer below $1.9 \mathrm{~km}$, however, that controls aerosol influx into the boundary layer over land, hence its use here. In the continental background and urban outflow regimes, data from below $100 \mathrm{~m}$ were removed to avoid bias, as the aircraft only flew at this altitude over land in the vicinity of the airport; the airport's influence was found to be negligible above this altitude. Urban outflow data were from the centre of the nearfield $(<60 \mathrm{~km})$ urban plumes emitted from the cities listed above. These data were confined to include only measurements where $\mathrm{NO}_{x}$ levels were within the highest $5 \%$ measured during the campaign ( $3.2 \mathrm{ppbv})$.

\subsection{Regional modelling}

Two regional-scale models were used to test the hypothesis that aerosol measured by the aircraft over the sea is transported from central Africa: the COSMO-ART (Consortium for Small-scale Modelling - Aerosol Reactive Trace gases) model is an online chemistry-transport model and is used to provide a high-resolution ( $2.5 \mathrm{~km}$ grid resolution) evaluation of a relatively short time period. This model has the advantage of being able to be used to investigate the impacts of biomass burning on cloud microphysical properties. GEOS-Chem (http://acmg.seas.harvard.edu/geos/, last access: 8 November 2018) is an offline chemistry-transport model run at a coarse resolution $\left(0.25^{\circ} \times 0.23125^{\circ}\right)$, but with the advantage of being able to be run for a longer time period.

COSMO-ART is based on the German Weather Service's (DWD) operational weather forecast model COSMO (Baldauf et al., 2011), coupled with an aerosol model (ART) for online treatment of aerosol chemistry and dynamics (Vogel et al., 2009; Bangert et al., 2012; Athanasopoulou et al., 2014; Knote et al., 2011). The interaction of aerosols with liquid and ice clouds was simulated using the two-moment microphysics scheme of Seifert and Beheng (2006). For the liquid phase a parameterisation of Phillips et al. (2008) was applied (for details, see Bangert et al., 2012, and Rieger et al., 2014). This allows feedbacks between aerosols and radiation as well as between aerosols and clouds to be calculated.

Emission data from EDGAR (2010) (Emission Database for Global Atmospheric Research) were used for the anthropogenic emission of gases and aerosols. Natural emissions of biogenic volatile organic compounds (Weimer et al., 2017), sea salt (Lundgren et al., 2013), dimethyl sulfide (DMS; Lana et al., 2011), mineral dust (Stanelle et al., 2010; Rieger et al., 2017) and GFAS (Global Fire Assimilation System) emissions from vegetation fires (Kaiser et al., 2012; Walter et al., 2016) are calculated online for each model time step. Gas-flaring emissions are prescribed following Deetz and Vogel (2017). Meteorological initial and boundary conditions are taken from the operational global Icosahedral Nonhydrostatic (ICON) model (Zängl et al., 2015) runs of the DWD. Initial and boundary conditions for gaseous and particulate compounds are derived from Model for Ozone and Related chemical Tracers (MOZART) forecasts (Emmons et al., 2010).

There was a spin-up period of $7 \mathrm{~d}$ (19 June to 5 July 2016) and results are presented for $24 \mathrm{~h}$ on 6 July 2016 . Two simulations were performed for this study: one with the biomass burning emissions (both near-field and remote) included and the other without. The simulations were performed over a large domain (D1) covering West Africa and the south eastern Atlantic Ocean with a grid size of $5 \mathrm{~km}$ and 50 vertical layers. The output from D1 was used to provide boundary conditions for a smaller, nested domain (D2) covering southern West Africa (the DACCIWA region), with a grid spacing of $2.5 \mathrm{~km}$ and 80 vertical levels (see Fig. 2). Although domain D1 covers a large area, COSMO-ART is still a limited area model. Comparing Fig. 2 with Fig. 8a it is therefore evident that D1 misses about $20 \%$ of the fire emissions of central Africa. However, this is likely compensated for by the provision of boundary conditions for gaseous and particulate compounds of the global model system MOZART (2017).

GEOS-Chem is a three-dimensional model of tropospheric chemistry (Bey et al., 2001; Wang et al., 2004), driven with offline meteorological input from the NASA Goddard Space Flight Center's Global Modeling and Assimilation Office. This study uses GEOS-Chem version 11-01 (http://wiki.seas. harvard.edu/geos-chem/index.php/GEOS-Chem_v11-01, last access: 8 November 2018). Simulations were performed globally at a horizontal resolution of $2^{\circ} \times 2.5^{\circ}$ to provide boundary conditions for the regional (latitudes $6^{\circ} \mathrm{S}-6^{\circ} \mathrm{N}$, longitudes $18.125^{\circ} \mathrm{W}-26.875^{\circ} \mathrm{E}$ ) West Africa model at a resolution of $0.25^{\circ} \times 0.3125^{\circ}$. Simulations have 47 vertical levels from the surface to $0.01 \mathrm{hPa}$, using meteorological 


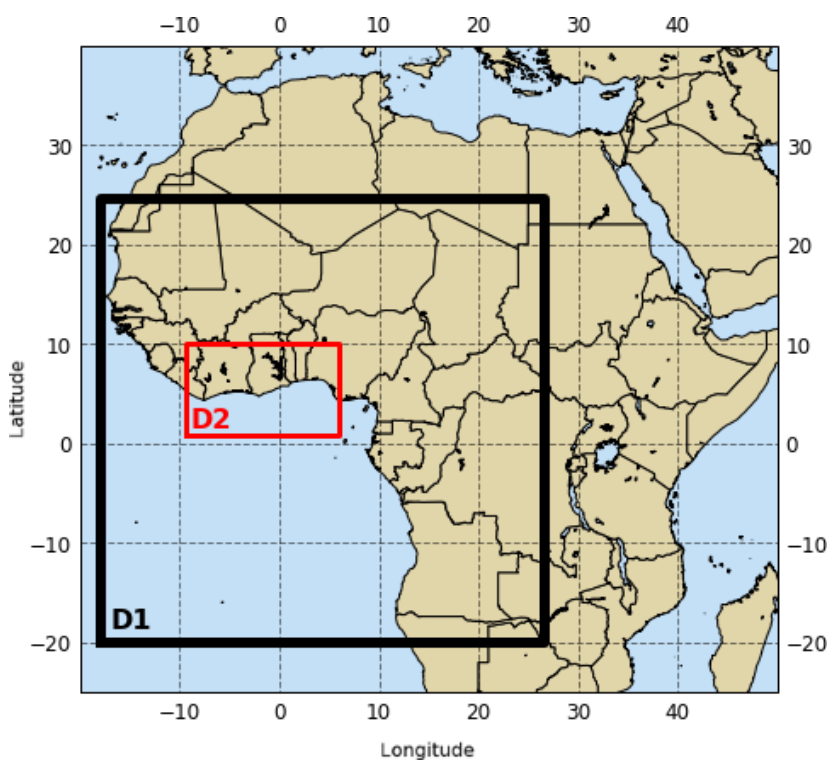

Figure 2. The two nested domains used by the COSMO-ART model.

data produced by the NASA Goddard Space Flight Center's Global Modeling and Assimilation Office. The model was run for the period from 29 June to 16 July 2016 (the duration of the DACCIWA aircraft campaign) with a 2-week spin-up period.

The model uses EDGAR v4.2 (EC-JRC/PBL, 2011) for anthropogenic emissions, which is overwritten by regional inventories where available: EMEP for Europe, NEI for the USA, CAC for Canada, MIX for South East Asia and BRAVO for Mexico. Over Africa, the DACCIWA inventory (Junker and Liousse, 2008; Knippertz et al., 2015) is used for anthropogenic emissions. The Global Fire Assimilation System (GFAS) data are used for biomass burning emissions with a scale factor of 3.4 applied to the organic carbon emissions as recommended by Kaiser et al. (2012). The model uses MEGAN v2.1 (Guenther et al., 2012) for biogenic emissions of volatile organic compounds, biogenic soil $\mathrm{NO}_{x}$ emissions from Hudman et al. (2012) and interactive lightning $\mathrm{NO}_{x}$ (Murray et al., 2012). More details of the processing of organic aerosol in the model can be found in Park et al. (2003).

\section{Results and discussion}

\subsection{Observations}

Figure 3 shows the aerosol particle number size distribution observed in each of the three regimes considered here. Significant variation can be seen in the number of smaller, Aitken mode particles, here considered to be those smaller than $100 \mathrm{~nm}$. These particles are emitted from urban centres or formed from precursor gases and grow quickly in the at- mosphere; large Aitken mode populations therefore indicate the presence of significant local sources. In the urban outflow regime, the Aitken mode concentration was often high, with a median number concentration of $3400 \mathrm{~cm}^{-3}$. In contrast, the Aitken mode was barely present in upwind marine air (median of $130 \mathrm{~cm}^{-3}$ ). The number concentration of accumulation mode particles, with an average diameter near $200 \mathrm{~nm}$, however, was remarkably consistent across the three regimes: $80 \%$ of the data lay within $\pm 30 \%$ of the campaign median in all cases. The median accumulation mode concentration was $600 \mathrm{~cm}^{-3}$ STP in the upwind marine air and $850 \mathrm{~cm}^{-3}$ STP in the continental background.

In the lower atmosphere during June and July, wind speeds in southern West Africa are generally low and wind comes from the south, becoming south-westerly as it approaches the coast. Therefore, within the monsoon layer, cool, moist Atlantic air progresses towards the cities and is likely to carry their plumes inland (Knippertz et al., 2017). Nevertheless, the similarity between the accumulation mode concentration in the upwind marine and continental background regimes seen here suggests that the air mass already contained a large number of the accumulation mode particles prior to urban influence. Comparing the median accumulation mode number concentrations in the continental background regime $\left(850 \mathrm{~cm}^{-3} \mathrm{STP}\right)$ and the upstream marine regime $\left(600 \mathrm{~cm}^{-3}\right.$ STP) suggests that, far from the source, city emissions and land-based biogenic sources contributed only an extra $40 \%$ on top of the incoming accumulation mode aerosol. This calculation assumes a constant influence across the region from incoming aerosol and so likely represents a lower limit. Nevertheless, this implies that incoming pollution from the Atlantic has a considerable influence on the aerosol population over the land.

The chemical composition of aerosols observed during DACCIWA supports the suggestion that much of the aerosol in the region originates upwind of the cities. Figure $4 \mathrm{a}$ shows aerosol mass and number concentrations in the three regimes, with mass classified by chemical species. The median total aerosol concentrations observed were 6.2, 11.1 and $7.5 \mu \mathrm{g} \mathrm{m}^{-3}$ in the upwind marine, urban outflow and background continental regime, respectively, with interquartile

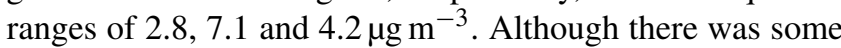
day-to-day variability, which can be seen in the interquartile ranges shown in Fig. 3, there was no statistically significant variation in the median throughout the diurnal cycle (the variation in the median throughout the day was $<1 \mu \mathrm{g} \mathrm{m}^{-3}$ ). Very little variation between the three regimes is seen in the proportional contribution of the different chemical species. The largest contribution to the measured $\mathrm{PM}_{1}$ (particulate matter with a diameter smaller than $1 \mu \mathrm{m}$ ) was organic aerosol, which accounted for approximately $60 \%$ of the aerosol mass in all three regimes. Sulfate accounted for approximately $25 \%$ and nitrate was generally low, comprising $4 \%-6 \%$. Ammonium contributed around $11 \%$. The largest aerosol mass loadings and number concentrations were observed in 

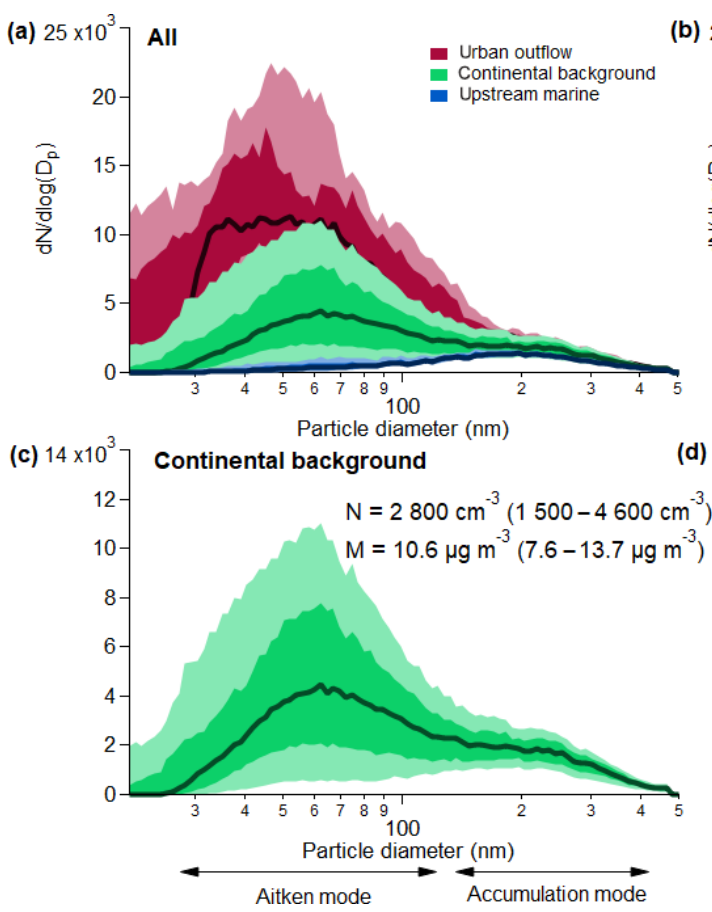

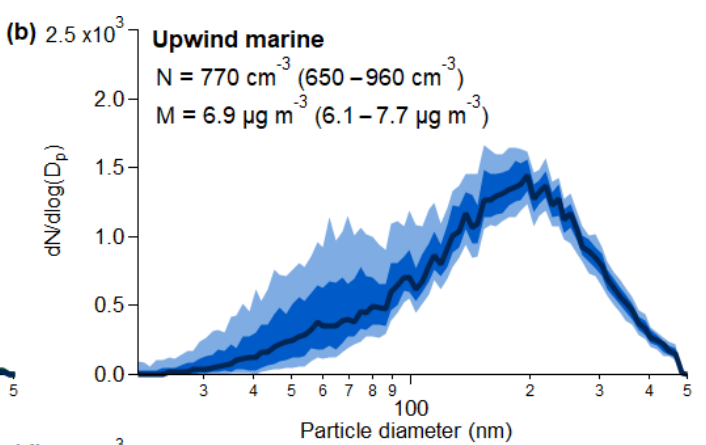

(d) $25 \times 10^{3}$

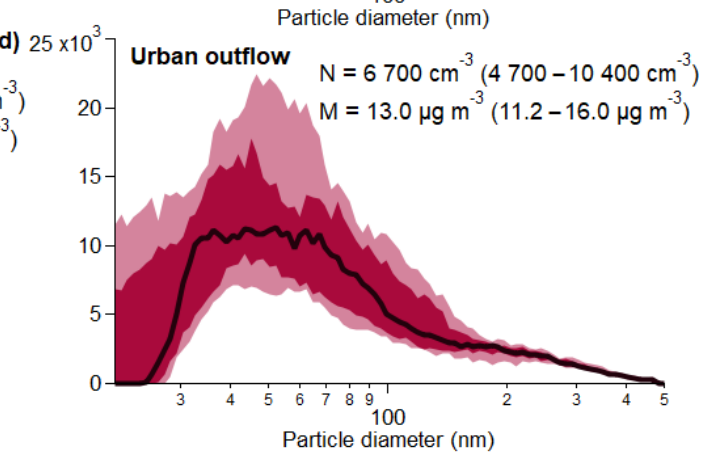

Figure 3. Size distributions of aerosol in the urban outflow, continental background and upstream marine regimes, measured by the SMPS on board the ATR aircraft. For each regime, the median size distribution is shown by the dark line, the dark shading contains $50 \%$ of the data, and the light shading contains $80 \%$ of the data. The comparison of all three plots in panel (a) shows a stable accumulation mode that exists in all three regimes, centred at around $200 \mathrm{~nm}$, while the smaller Aitken mode is much more variable. In panels (b)-(d), $N$ shows the median total number concentration summed across the whole distribution, with the lower and upper quartiles shown in brackets; $M$ shows the calculated aerosol mass, assuming an aerosol density of $1.6 \mathrm{~g} \mathrm{~cm}^{-3}$ (Haslett et al., 2019), with the interquartile range again shown in brackets. The Aitken and accumulation modes are labelled in panel (c).

the urban outflow, although, even here, accumulation mode aerosol present in incoming air could account for as much as $50 \%$ of the total mass. Figure $4 \mathrm{~b}$ shows the proportional chemical distribution for the three regimes explored here alongside those for the elevated biomass burning aerosol layer commonly sampled at $2-4 \mathrm{~km}$ from the ATR and Falcon, as well as the free troposphere above $5 \mathrm{~km}$ from the Falcon.

Figure $4 \mathrm{c}$ shows the modelled fine aerosol composition from COSMO-ART and GEOS-Chem. The COSMO-ART simulation is from 6 July, while that from GEOS-Chem is an average calculated from hourly output data from 29 June to 16 July 2016 (the duration of the DACCIWA aircraft campaign). The average concentrations in the upwind marine data $\left(4.45 \mu \mathrm{g} \mathrm{m}^{-3}\right.$ for COSMO-ART and $5.47 \mu \mathrm{g} \mathrm{m}^{-3}$ by GEOS-Chem) are in reasonable agreement with the observations $\left(6.3 \mu \mathrm{g} \mathrm{m}^{-3}\right)$. In the urban outflow, modelled concentrations increase $\left(11.52 \mu \mathrm{g} \mathrm{m}^{-3}\right.$ from COSMO-ART, $10.85 \mu \mathrm{g} \mathrm{m}^{-3}$ from GEOS-Chem) and are again generally consistent with the observations $\left(11.1 \mu \mathrm{g} \mathrm{m}^{-3}\right)$. In continental background air, however, there is a discrepancy, with COSMO-ART simulating $1.90 \mu \mathrm{g} \mathrm{m}^{-3}$, while GEOSChem calculates $8.28 \mu \mathrm{g} \mathrm{m}^{-3}$; observations found an average of $7.5 \mu \mathrm{g} \mathrm{m}^{-3}$. Several factors could be responsible for the COSMO-ART response: (i) failure to simulate the inland progression of the marine air far enough northwards; (ii) overestimation of aerosol losses in the model, potentially due to vertical mixing being too strong over land; and (iii) the model simulation being for a specific day, while observed results are from flights performed at different times during the DACCIWA campaign.

Switching off the biomass burning emissions over central Africa and West Africa reduces aerosol concentrations in both models. Models attribute $\sim 75 \%$ of the upwind marine and $\sim 50 \%$ in the urban outflow of the aerosol mass to the biomass burning, with the vast majority of that occurring in central Africa (see Sect. 3.2). From these model studies we conclude that the majority of the fine aerosol seen in the upwind marine, and a significant fraction of that seen in the urban outflow, is of biomass burning origin.

The proportion of organic aerosol in the monsoon layer was large compared with what has been seen in other locations dominated by a mix of urban or biogenic emissions: Zhang et al. (2011) found that the global average organic fraction measured by the AMS is between $43 \%$ in remote locations and $52 \%$ downwind from urban centres. The contribution of nitrate here, in contrast, was lower than is typically seen in locations influenced by urban outflow. Zhang et 

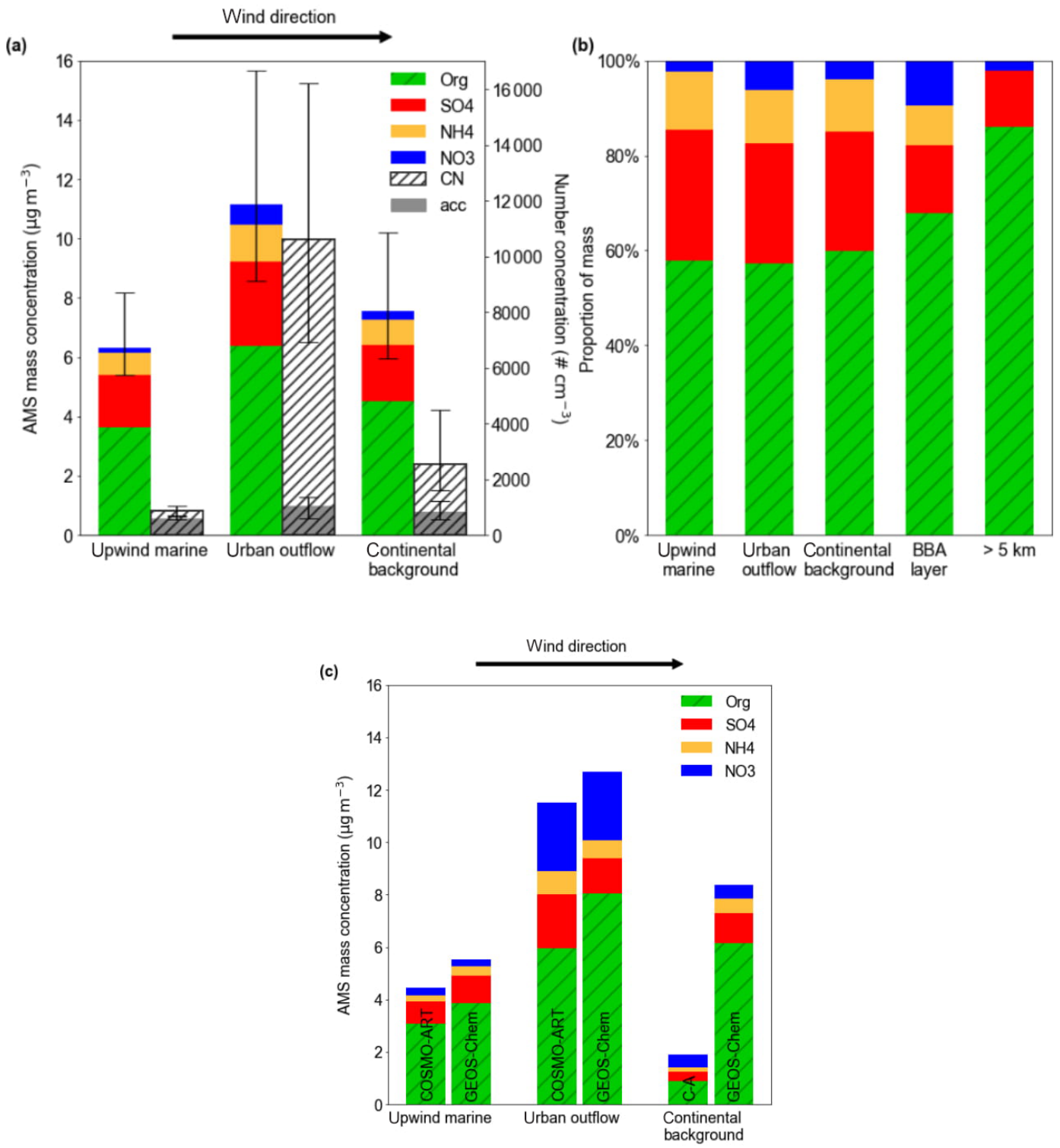

Figure 4. (a) The observed chemical composition and condensation nucleus $(\mathrm{CN})$ concentration in each of the three regimes. Coloured bars indicate aerosol mass concentration measured by the AMS. The CN bars show the total aerosol number concentration in each location (measured by the $\mathrm{CPC}$ ), with shaded regions indicating the number of aerosol particles in the accumulation mode (derived from SMPS data shown in Fig. 3). Bars indicate the median, with error bars showing the interquartile range of observations (for total aerosol in the case of the AMS). A similar chemical distribution can be seen in each of the three regimes. (b) A comparison of the aerosol chemical distribution in all three regimes, alongside observations from the biomass burning layer at 3-4 km altitude (ATR and Falcon; labelled "BBA layer") and the free troposphere (>5 km; Falcon) for comparison. (c) Aerosol composition in the three regimes simulated by the COSMO-ART and GEOS-Chem models.

al. (2011) found a global average contribution of $12 \%$ and $18 \%$ in downwind and urban locations, respectively, which is much larger than was observed here. The high sulfate loading in the upwind marine regime is typical of marine aerosol, though in this case there is also likely a contribution from biomass burning. Sulfate over the oceans can originate from sea salt, as well as from the oxidation products of dimethyl sulfide (DMS) produced by phytoplankton. Non-sea-salt sul- fate is typically found in concentrations of $0.2-1.5 \mu \mathrm{g} \mathrm{m} \mathrm{m}^{-3}$ in marine aerosol (Choi et al., 2017; Fitzgerald, 1991). In the inland regions, this likely mixes with sulfate produced from the cities.

The aerosol composition here is comparable with measurements during the dry season in South Africa, which can be influenced by emissions from savannah burning (Tiitta et al., 2014). The high contribution from organic aerosol is 
similar to observations of biomass burning plumes made in West Africa during 2006 as part of the DABEX (Dust and Biomass burning Experiment; Capes et al., 2008), as well as those made from biomass burning plumes in southern Africa (Vakkari et al., 2014). The key difference here is the large sulfate contribution, which is likely due to the influence of marine emissions.

The organic mass spectra from the AMS on board the Twin Otter and the ATR for the three regimes are shown in Fig. 5, alongside the mass spectrum of the biomass burning layer at $2-4 \mathrm{~km}$ from the Falcon AMS, which is widely considered to have originated from central Africa (Flamant et al., 2018). All four spectra are dominated by aged organic aerosol, which is characterised by strong peaks at $m / z 28$ and 44 ( $\mathrm{Ng}$ et al., 2011). Although the $2-4 \mathrm{~km}$ biomass burning layer showed a chemical distribution containing more organics and nitrate and less sulfate than aerosol observed lower in the atmosphere (Fig. 4b), the organic mass spectra shown here for this layer is very similar to that of the upstream marine aerosol, with $\mathrm{m} / \mathrm{z} 28$ and $\mathrm{m} / \mathrm{z} 44$ comprising $50 \%$ of the total organic mass in both cases. The urban outflow and, to a lesser extent, continental background mass spectra show features characteristic of urban pollution, including peaks at $m / z 42,55$ and 91, which are associated with internal combustion engines ( $\mathrm{Ng}$ et al., 2011), as well as a number of clustered hydrocarbon peaks, for example at $m / z$ 65, 67 and 69 or $m / z 79,81$ and 83 . A peak can be seen in the urban outflow and continental background regimes at $m / z 60$, which is often associated with levoglucosan and other anhydrous sugars from biomass burning (Cubison et al., 2011) and likely arises from the widespread use of individual stoves for cooking, both in cities and in rural areas. This peak is associated only with fresh biomass burning; due to the oxidisation of anhydrous sugars in the atmosphere (Henningan et al., 2011), it would no longer be strongly visible in the spectrum after a few days of processing (Cubsion et al., 2011). These features together indicate that local urban and fresh biomass burning sources do contribute to the aerosol mass loading in the monsoon layer over southern West Africa. However, there appears to be a further, significant and considerably more aged source, which is entering the region from the south and has resulted in all four mass spectra being dominated by the oxidised peaks $m / z 28$ and $m / z$ 44. This analysis is supported by a positive matrix factorisation (PMF) factor analysis that was carried out by Brito et al. (2018). The study identified a factor of highly aged, oxidised organic aerosol, which was relatively homogeneously present across the entire DACCIWA campaign region, including over the Atlantic Ocean south of the coast.

The dominance of aged aerosol in the overall population can be demonstrated further by comparing the magnitude of the $m / z 44$ peak with the total organic mass. Five-minute averaged datapoints from the Twin Otter aircraft are shown as markers in Fig. 6a. The dataset shown includes the continental background and urban outflow regimes; the median ob- servation for each regime, including upwind marine, is also displayed. The $m / z 44$ contribution here correlates well with the total organic mass $(r=0.78)$, with $m / z 44$ contributing around $15 \%$ throughout the campaign.

The relationship between $\mathrm{m} / \mathrm{z} 44$ and the total organic aerosol mass can provide some insight into the source of ambient aerosol. The pink and blue lines in Fig. 6a show the averages across several campaigns from different parts of the globe for two different factors derived using the PMF, as compiled by $\mathrm{Ng}$ et al. (2011). PMF is a technique used to analyse the contributions of different aerosol sources to an AMS dataset and identify a mass spectrum associated with each source based on its variation in time. Two factors commonly identified by PMF include oxidised organic aerosol (OOA) and hydrocarbon-like organic aerosol (HOA). The highly oxidised OOA factors are generally associated with photochemically aged aerosol, with $\mathrm{m} / \mathrm{z} 44$ contributing a significant fraction of the total organic aerosol mass, as is shown by the higher gradient of the pink OOA line in Fig. 6 a. The HOA fractions are often seen in pure fresh urban emissions. The contribution of $\mathrm{m} / \mathrm{z}$ to the total organic aerosol is significantly lower in these cases, with the $m / z 44$ peak typically contributing less than $2 \%$ of the mass. This can be seen in the shallow gradient of the blue HOA line in Fig. 6a. In urban environments, mass spectra would be expected to have a large HOA component, and thus a large amount of scatter would be expected in the data, with the majority lying between the OOA and HOA lines. Here, the data are scattered predominantly around the OOA line, which suggests that the urban contribution is not the dominant factor in this dataset. The most significant proportion of the aerosol measured during the campaign is from aged, oxidised organic aerosol.

The presence of a peak at $m / z 60$ in the continental background air suggests that local biomass burning is present in the observed air mass. This is explored in more detail in Fig. 6b. It has been shown previously that fresh biomass burning contains a large fraction of $m / z 60(f 60)$, a fragment of levoglucosan, which decreases as the plume ages. Furthermore, as the plume becomes more oxidised, the fraction of $m / z 44$ ( $f 44)$ increases. Thus, fresh biomass burning emissions populate the bottom of the triangle shown in Fig. $6 \mathrm{~b}$ and move towards the top corner in the direction shown by the arrow as they age (Cubison et al., 2011). The dashed line to the left shows the expected baseline values for air not containing any fresh biomass burning. Here, $f 60$ is consistently slightly higher than the baseline, suggesting the presence of some fresh biomass burning. However, $f 60$ is not high enough at any time to suggest that fresh biomass burning is the dominant source of aerosol. The values of $f 44$ are generally high, which again shows the prevalence of aged organic aerosol in the air mass.

The relationship between the organic aerosol mass concentration and $\mathrm{CO}$ enhancement over the baseline $(\triangle \mathrm{CO})$ is shown in Fig. 7a. Given its long atmospheric lifetime (Wang and Prinn, 1999), CO can be used as an inert tracer to ac- 


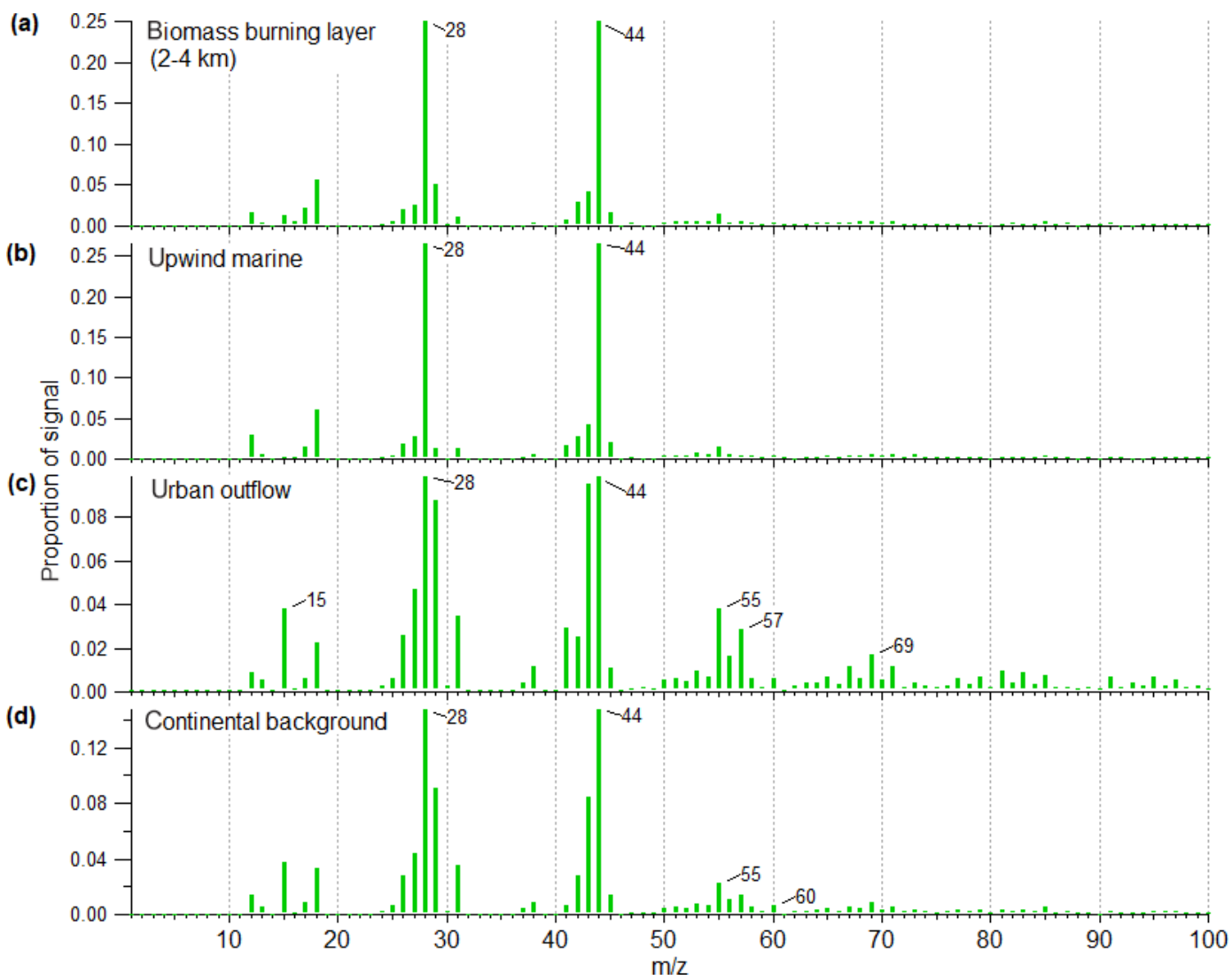

Figure 5. Average organic aerosol mass spectra in (a) the $2-4 \mathrm{~km}$ biomass burning layer (from the Falcon AMS) and (b-d) each of the three regimes (ATR and Twin Otter). The influence of fresh urban emissions can be seen in the urban outflow regime and, to a lesser extent, in the continental background, demonstrated by the higher proportion of $m / z 55$ and 57, alongside larger hydrocarbon clusters. Fresh biomass burning is indicated by the peak at $m / z 60$. However, the dominant contribution in all cases is from $m / z 28$ and 44 , both indicators of aged, oxidised organic aerosol.

count for the effects of dilution. A line of regression therefore indicates the source strengths and deviation from this line arise from changes in the organic aerosol due to photolytic effects, secondary organic aerosol (SOA) enhancements, wet removal or dry deposition. The intercept of the $\mathrm{CO}$ axis in this case within the monsoon layer is at $0.11 \mathrm{ppmv}$, which is taken in further calculations to be the baseline across the region. The intercept above the monsoon layer was slightly lower, at 0.10 .

The emission ratio $\Delta \mathrm{OA} / \Delta \mathrm{CO}$ (where $\Delta \mathrm{OA}$ is organic aerosol enhancement above zero) in fresh urban plumes is usually lower than $20 \mathrm{\mu g} \mathrm{m}^{-3} \mathrm{ppmv}^{-1}$, though once SOA has formed this increases to between 40 and $100 \mu \mathrm{g} \mathrm{m}^{-3} \mathrm{ppmv}^{-1}$ (DeGouw and Jimenez, 2009). Unlike environments dominated by urban emissions, the $\triangle \mathrm{OA} / \Delta \mathrm{CO}$ in biomass burning plumes is considerably more variable, with ratios having been observed between 45 and $200 \mu \mathrm{g} \mathrm{m}^{-3} \mathrm{ppmv}^{-1}$. Capes et al. (2008) reported an emission ratio of approximately $175 \mu \mathrm{g} \mathrm{m}^{-3} \mathrm{ppmv}^{-1}$ in West Africa during the DABEX campaign in 2006, while Vakkari et al. (2014) reported ratios between 50 and $200 \mathrm{\mu g} \mathrm{m}^{-3} \mathrm{ppmv}^{-1}$ for biomass burning plumes in southern Africa. The high variability in ratios between different fires is likely related to the variable properties of the individual fire events (Jolleys et al., 2012), as well as to differences in atmospheric ageing processes (Vakkari et al., 2014).

Here, the low emission ratio in the urban outflow $\left(51 \mu \mathrm{g} \mathrm{m}^{-3} \mathrm{ppmv}^{-1}\right)$ is slightly higher than would be expected for a fresh urban plume; this may be related to both the large amounts of biomass burning in the city and the background aerosol. The ratio in the elevated biomass burning layer was considerably higher $\left(225 \mathrm{\mu g} \mathrm{m}^{-3} \mathrm{ppmv}^{-1}\right)$. In the upwind marine $\left(142 \mu \mathrm{g} \mathrm{m}^{-3} \mathrm{ppmv}^{-1}\right)$ and continental background $\left(116 \mu \mathrm{g} \mathrm{m}^{-3} \mathrm{ppmv}^{-1}\right)$ regimes, the value was higher than would be expected from even an aged urban plume. Many of the datapoints in Fig. 7a fall along the same line as the elevated biomass burning layer. These results provide a strong suggestion that much of the aerosol measured during the DACCIWA aircraft campaign did not originate from urban pollution but from biomass burning.

Figure $7 \mathrm{~b}$ show modelled concentrations of $\mathrm{CO}$ from the GEOS-Chem model in the upwind marine regime, with the 

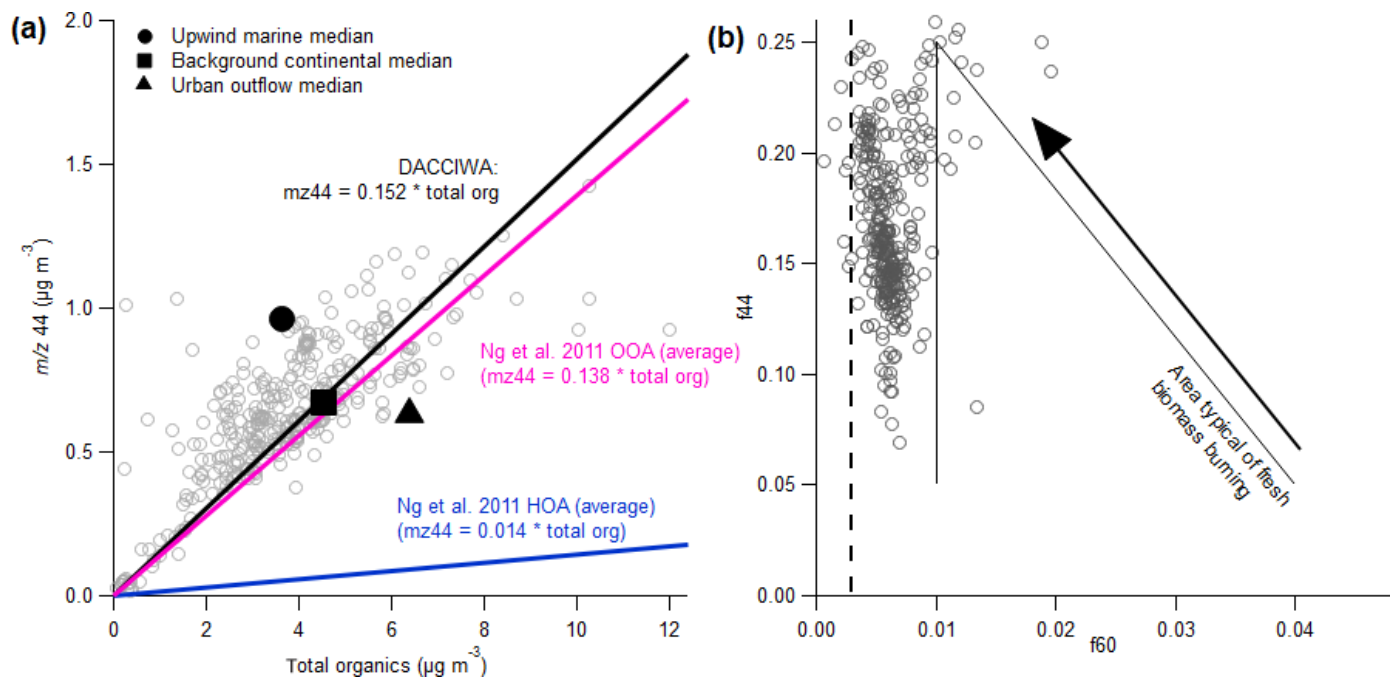

Figure 6. (a) Values of $m / z$ 44, a strong indicator of aged organic aerosol, plotted against the total organic aerosol mass. The pink and blue lines show the average contribution of $\mathrm{m} / \mathrm{z}, 44$ to the total for oxidised organic aerosol (OOA) and hydrocarbon-like organic aerosol (HOA). Grey circular markers show datapoints from the DACCIWA campaign. Median observations from each of the three regimes are shown as black shapes. (b) The fractional contribution of $m / z 44(f 44)$ vs. $m / z 60(f 60)$. Fresh biomass burning aerosol is generally located within the triangle shown by the two black lines (Cubison et al., 2011), with fresher aerosol lower in the triangle. The dashed line is representative of aerosol that is not from fresh biomass burning. While $\mathrm{m} / \mathrm{z} 60$ aerosol is present here, the low contributions suggest that fresh biomass burning is not a dominant contributor towards the total organic aerosol mass.

emissions from biomass burning switched off in the first model run and on in the second. This is shown alongside observed values of $\mathrm{CO}$ for each of the three regimes. The model results were only comparable with observations when biomass burning emissions were included, suggesting a significant influence from biomass burning over the ocean.

\subsection{Southern and central African biomass burning}

The lack of variability in the accumulation mode concentration and composition is evidence that much of the aerosol observed during the DACCIWA campaign originated from a similar type of source. Furthermore, the similarity between these characteristics across the three regimes, including the upwind marine, identifies the dominant source to be outside the urban coastal region, upwind of all three locations. A closer inspection of the organic aerosol mass spectra during DACCIWA suggests the presence of a large mass of aged aerosol, with smaller contributions from fresh urban and fresh biomass burning sources.

Aerosol in the upwind marine regime is unlikely to have originated from either the coastal cities or from oil fields over the Atlantic Ocean. The southerlies in the monsoon layer in this region are very stable, with an onshore flow during both the day and the night (Flamant et al., 2018; Guedje et al., 2019). Transport from land to sea is therefore largely impeded by the superposition of the sea breeze circulation with this strong southerly monsoon flow. As a result, city pollution is mostly transported inland and hardly reaches beyond $50 \mathrm{~km}$ south of the shoreline - even less when the souther- lies are stronger (Flamant et al., 2018). A pilot balloon climatology by Guedje et al. (2019) for Cotonou reveals that during July-September the flow below $1 \mathrm{~km}$ is exclusively from the southerly quadrants, while at higher altitudes a weak northerly component occurs only occasionally. Radiosonde measurements from coastal stations show that there is hardly a northerly component in the wind direction at all (Flamant et al., 2018). Aerosol mass in the upwind marine regime is therefore unlikely to have originated from the cities and have been transported south of the coast. Studies of oil rig emissions over the Atlantic carried out during the DACCIWA campaign show that these emissions are characterised by narrow plumes of pollution that are strongest close to the source and which have generally dispersed after $40 \mathrm{~km}$ (Brocchi et al., 2019). This profile of spikes in $\mathrm{CO}, \mathrm{NO}_{x}$ and aerosol emissions was not observed during the flights that are considered here, making it unlikely that they were influenced by oil field emissions. This evidence therefore shows that a large proportion of the aerosol mass in the continental West African boundary layer originates from the monsoon layer over the eastern tropical Atlantic Ocean and is present prior to the influence from coastal cities.

One of the most significant fine-mode aerosol sources south of the coastal cities is the agricultural and savannah burning that takes place annually in central and southern Africa between June and September (Barbosa et al., 1999). Vast quantities of biomass burning aerosol are injected into the mid-troposphere between 3 and $4.5 \mathrm{~km}$ as a result of these fires (Labonne et al., 2007) and carried west over the Atlantic 
(a)

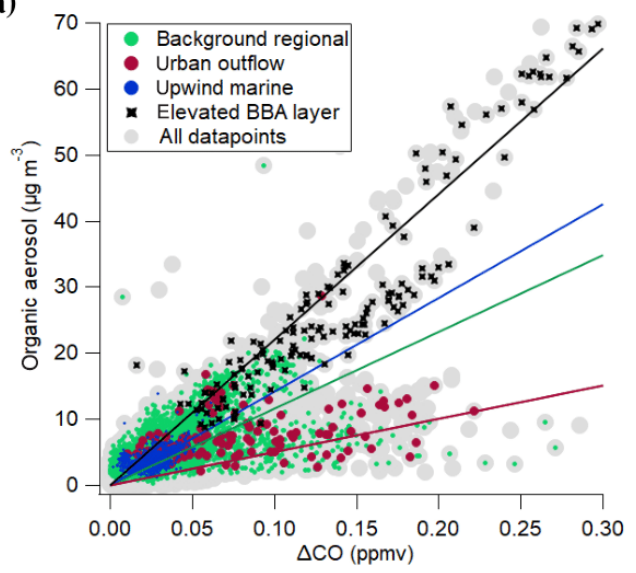

(b)

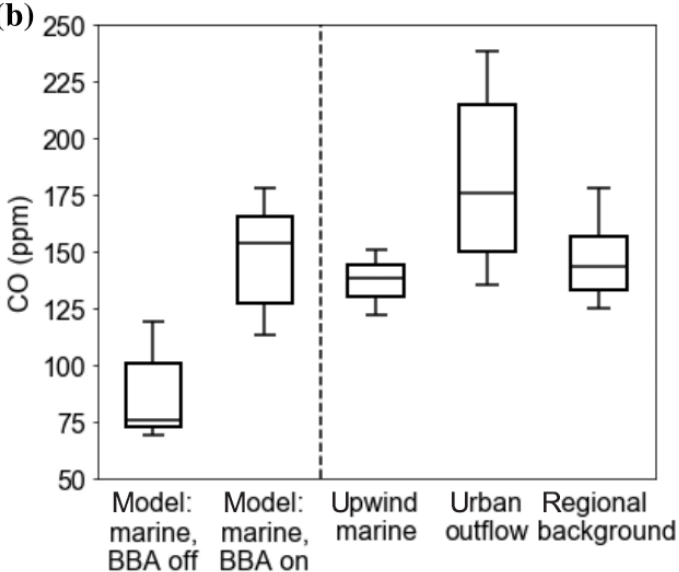

Figure 7. (a) The ratio of organic aerosol to $\mathrm{CO}$, with lines of regression included for each of the three regimes and the elevated $\mathrm{BBA}$ layer between 2 and $4 \mathrm{~km}$. CO is shown as enhancement above the background $(0.11 / 0.10 \mathrm{ppmv}$ for in/above the monsoon layer). (b) CO concentrations. Modelled results from GEOS-Chem show the CO concentration in the upwind marine regime with biomass burning emissions off/on. Observational results are shown from all three regimes. The model simulation is only comparable with observational measurements when biomass burning is considered.

(a)
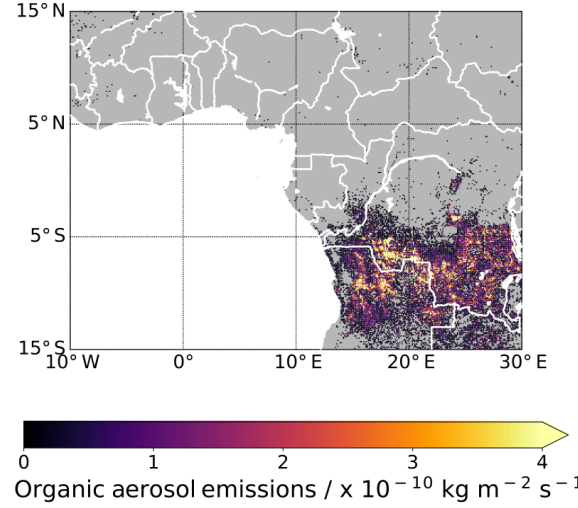

(b)

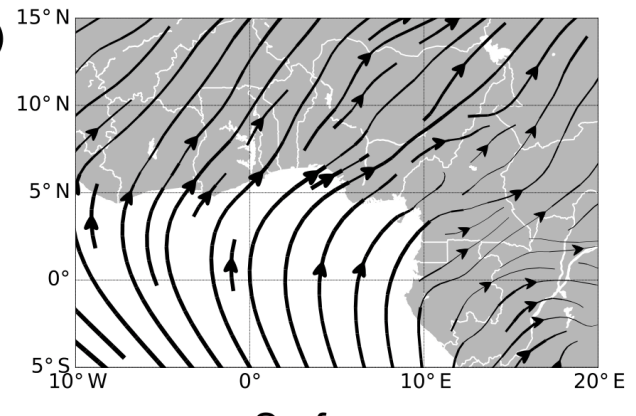

(c)

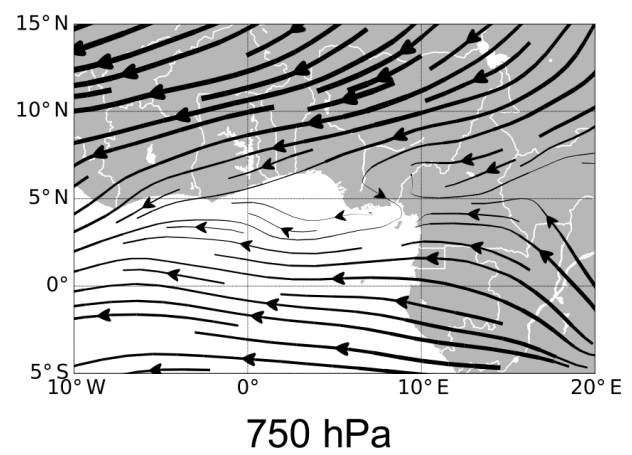

Figure 8. (a) The location and intensity of organic aerosol emissions from biomass burning in central Africa during the DACCIWA campaign (June-July 2016) from the GFAS inventory (Kaiser et al., 2012), (b, c) Wind stream functions at (b) the surface level and (c) $750 \mathrm{hPa}($ approx. $2.5 \mathrm{~km}$ ) from the NASA Global Modelling and Data Assimilation Office's GEOS-FP analysis. The line thickness indicates wind speed.

Ocean by tropospheric winds at around $700 \mathrm{hPa}$ (Das et al., 2017; Edwards et al., 2006). The location and intensity of these fires during the DACCIWA aircraft campaign is shown in Fig. 8, alongside modelled wind streams at ground level and at $750 \mathrm{hPa}$. At $750 \mathrm{hPa}$, the easterly currents that carry biomass burning pollution west out of central Africa can be clearly seen, while the surface level chart shows the southerly air stream that passes from the Atlantic Ocean into the southern West African monsoon layer. 
The observations of the aerosol composition in the continental monsoon layer during the DACCIWA campaign described above show it to be characteristic of aged biomass burning aerosol. The proportion of organic aerosol was higher and nitrate was lower than would be expected in areas influenced primarily by urban outflow (Zhang et al., 2011). The mass spectra of organic aerosol below $1.9 \mathrm{~km}$ were dominated by peaks typical of aged, low-volatility aerosol, which closely resembled the mass spectrum of the $2-4 \mathrm{~km}$ biomass burning layer. Even in the urban outflow regime, mass spectral features associated with near-field urban sources such as internal combustion engines were less prominent than would be expected from pure urban aerosol. This evidence supports the assertion that these central and southern African fires are the primary source of accumulation mode aerosol in southern West Africa during the summer monsoon season.

Recent observations carried out on Ascension Island to the south-west of the DACCIWA region $\left(7.93^{\circ} \mathrm{S}, 14.42^{\circ} \mathrm{W}\right)$ as part of the US Department of Energy Atmospheric Radiation Measurement Layered Atlantic Smoke Interactions with Clouds (LASIC) campaign show that smoke from these fires can be detected at the planetary surface (Zuidema et al., 2018). This demonstrates that the central and southern African biomass burning aerosol plume is commonly entrained into the monsoon layer of the remote tropical Atlantic Ocean to the south of the DACCIWA region. This confirms that there is a pathway for biomass burning aerosol to enter the monsoon layer across large parts of the tropical eastern Atlantic. Once this biomass burning aerosol has been entrained into the monsoon layer, the prevailing southerly trade winds at the surface will carry it northwards towards the coast of southern West Africa. There was little evidence of precipitation over the eastern Atlantic and dry deposition rates of accumulation mode aerosol over open ocean are low. Once entrained, any aged biomass burning aerosol from central and southern Africa would therefore be advected into the DACCIWA region with little further loss. It has been shown that biomass burning emissions in Africa are among the least variable in the world on annual timescales (Voulgarakis et al., 2015). This implies that this influence on the southern West African monsoon layer is likely to be a consistent feature of the West African Monsoon.

In a recent multi-model evaluation, the extent of the plume's entrainment into the monsoon layer over the Atlantic Ocean proved difficult to model consistently (Das et al., 2017), with many models showing the plume descending too rapidly. In contrast, Gordon et al. (2018) use the HadGEM climate model to show the plume remaining above the clouds between 2 and $4 \mathrm{~km}$ and not descending at all until approximately $10^{\circ} \mathrm{W}$. A modelling study by Deroubaix et al. (2018) compared the impacts of long-range-transported biomass burning aerosol with that of local anthropogenic pollution during the monsoon season observed by the AMMA campaign in 2006. In this study, it was found that long-range transport of biomass burning aerosol was likely to contribute around $52 \%$ of the aerosol below $1 \mathrm{~km}$ in southern West Africa.

Results from the DACCIWA campaign verify the presence of regular biomass burning plume intrusions at altitudes of 2-4 km over the West African continent, with high aerosol loadings above $60 \mathrm{\mu g} \mathrm{m}^{-3}$ being observed at this altitude in some cases (Flamant et al., 2018). This is consistent with research suggesting that the majority of the southern and central African biomass burning plume remains above the clouds over the Atlantic Ocean (Adebiyi et al., 2015; Das et al., 2017; Gordon et al., 2018). However, results presented here show that, in addition, a significant proportion of the aerosol mass from the biomass burning plume is being entrained into the monsoon layer, where it is likely to have a significant impact on cloud properties and human health, particularly for the large population living along West Africa's southern coast.

\subsection{Aerosol influence on cloud properties}

Clouds' susceptibility to increased accumulation mode aerosol decreases when an aerosol background already exists. The relationship between aerosol concentration and cloud droplet number concentration is governed by a power law (Duong et al., 2011; McComiskey and Feingold, 2008; Ramanathan et al., 2001; Terai et al., 2012), so increasing the aerosol number concentration has a proportionally greater impact on clouds that would otherwise have formed in clean air. Furthermore, the change in albedo from increasing the number of water droplets is greater in a cloud with an initially low concentration (Twomey, 1977). Below around $100 \mathrm{CCN} \mathrm{cm}^{-3}$, light scattering by low-level cloud is extremely sensitive to even small increases in aerosol concentration (Kaufman and Fraser, 1997; Kaufman et al., 2005; Ramanathan et al., 2001). This susceptibility decreases gradually; a similar change from a higher initial loading will have a substantially smaller impact. Lower susceptibility would be expected for a cloud forming in a region with an aerosol concentration of 600 particles $\mathrm{cm}^{-3}$ or more.

During June and July, extensive low-level cloud forms along the West African southern coast (Knippertz et al., 2011; Schrage and Fink, 2012). It has been speculated that, during the monsoon season, clouds above West Africa could be highly susceptible to increases in anthropogenic pollution (Knippertz et al., 2015). However, the presence of a significant quantity of biomass burning smoke in incoming wind from the Atlantic Ocean is likely to reduce this effect.

Here, the effect of such an influx of biomass burning aerosol on cloud formation in the region was investigated using the COSMO-ART model. Two simulations were carried out for 6 July: one including biomass burning aerosol (FIRE) and one without (NO FIRE). These simulations are used here to illustrate the difference made to cloud properties by increasing the accumulation mode aerosol concentration. Figure $9 \mathrm{a}$ and $\mathrm{b}$ show two-dimensional histograms of cloud 

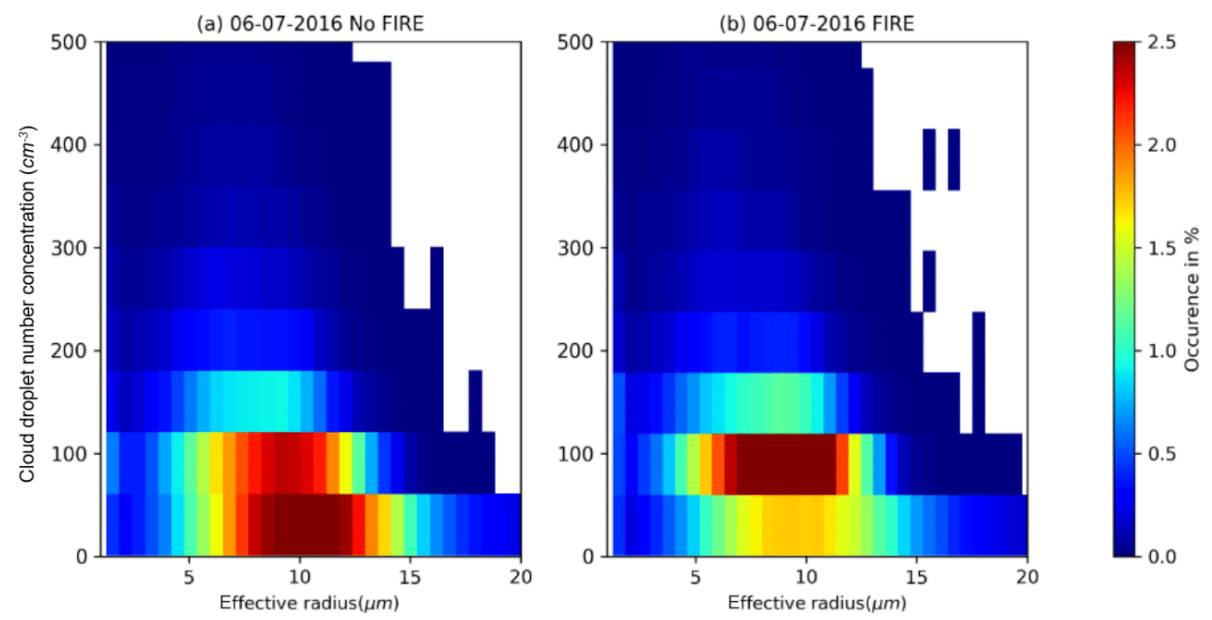

Figure 9. Two-dimensional histograms showing cloud properties in the NO FIRE (a) and FIRE (b) simulations conducted with COSMOART.

droplet number concentration and effective radius across the inner domain. In the NO FIRE case, the number concentrations are lower and the effective radii higher than in the FIRE case, with number concentrations increasing by up to $27 \%$.

These results show that remote biomass burning aerosol creates a significant background loading that systematically perturbs the cloud field. Any increase in anthropogenic emissions will be superimposed onto this existing background, reducing its influence on cloud. Thus, while enhancements in cloud droplet number concentrations in near-field city plumes were observed during the DACCIWA campaign, the influence of these plumes became indistinguishable further afield as they dispersed into the background. On a regional scale, city plumes were of secondary importance. This conclusion is supported by observations of cloud droplet number concentrations carried out during the DACCIWA campaign (Taylor et al., 2019).

\section{Summary and conclusion}

Observations of aerosol measurements below $1.9 \mathrm{~km}$ were collated from the three aircraft that took part in the DACCIWA aircraft campaign during June and July 2016. A regional background of pollution was observed across southern West Africa, which contained around $6.3 \mu \mathrm{g} \mathrm{m}^{-3}$ of dry aerosol in the accumulation mode and was dominated by aged organic matter. The lower atmosphere above the eastern tropical Atlantic Ocean, immediately upwind of the DACCIWA region, was similarly polluted. Mass concentrations of upwind pollutants here were typically around $80 \%$ of those over the land. Contributions from cities and local, smallscale biomass burning to the regional background was of secondary importance compared with this large aged aerosol mass. This aerosol background was attributed to large-scale biomass burning taking place in central and southern Africa.
Emissions become entrained into the monsoon flow over the Atlantic Ocean and are advected northwards into the southern West African region. Aerosol concentrations simulated using the COSMO-ART and the GEOS-Chem models support this conclusion, showing that concentrations in the upwind marine and urban outflow regimes could not be replicated without remote biomass burning emissions being taken into account.

The chemical composition of this aerosol background is consistent with aged biomass burning being advected over the continent in the monsoon layer. Markers of oxidised aerosol dominated the organic mass spectra in all locations with a ratio to total organics that is typical for more aged aerosol. Urban aerosol and the signature of local biomass burning are present, but both play a minor role compared with the larger quantity of aged aerosol. Although there was some day-to-day variability in the total mass concentration, the aerosol background was observed across the entire region with very little variation in chemical composition, suggesting a large-scale, distant source. If this were related to locally produced aerosol, greater variability would be expected across the region, with larger distinctions between urban outflow and rural measurements. Locally produced aerosol would be unlikely to be observed over the ocean as far upwind of the coast as it has been observed here, and the composition of the upwind aerosol does not resemble recycled urban emissions. It has been shown in previous DACCIWA studies that circulation of urban emissions over the ocean does not extend more than $50 \mathrm{~km}$ south of the southern West African coast (Flamant et al., 2018). Biomass burning from central and southern Africa is the most likely source of a large-scale mass of homogeneous aerosol in this region. This conclusion is consistent with observations from other campaigns that show biomass burning smoke is present at this time of year in the monsoon layer further south in Ascension Island (Zuidema et al., 2018). 
Results presented here suggest that the biomass burning pollution accounts for up to $80 \%$ of the accumulation mode aerosol mass over the continent. Given this large moderating effect on the air pollution over West Africa at this time of year, the microphysics of the prevalent stratiform clouds in the West African Monsoon is likely already largely perturbed even before near-field anthropogenic pollution is taken into consideration. Simulations using the COSMO-ART model showed significant differences in the cloud droplet number concentration and effective radius of cloud droplets when this biomass burning influx was taken into account. The cloud droplet number concentration increased by up to $27 \%$ over the marine domain when biomass burning was switched on. This suggests that significant increases in anthropogenic pollutants could have a smaller perturbing effect than would have been the case if incoming air were less polluted (Taylor et al., 2019).

This study takes place in the context of a strong focus in the research community on the dynamics and effects of the African biomass burning plume. A number of campaigns, including LASIC, ORACLES, CLARIFY and AEROCLO (Zuidema et al., 2016), have recently been carried out over the Atlantic Ocean west of the African continent, with the aim of better understanding this problem and quantifying the direct and semi-direct aerosol effects of the plume, which can differ significantly depending on the altitude at which the plume spreads (Das et al., 2017). This study provides further motivation for understanding these processes, as it shows that the potential for biomass burning aerosol to become entrained into the southern West African monsoon layer can have significant implications for large populations in West Africa, in addition to its effects on radiative forcing.

The significant contribution of long-range emissions towards local pollution in southern West African coastal cities highlights the often unique challenges faced in policy creation in developing regions. The population in West Africa is currently almost 400 million and is expected to more than double in the next 30 years (UN, 2017), with a growing proportion living in cities along the southern coast. Thus, the monsoon layer aerosol described in this paper will increase the $\mathrm{PM}_{1}$ exposure of a large population by around $8 \mu \mathrm{g} \mathrm{m}^{-3}$ from June to September, based on observational evidence presented here. This is a considerable proportion of the $10 \mu \mathrm{g} \mathrm{m}^{-3}$ annual exposure recommended by the World Health Organisation (WHO, 2005).

During the dry season (November-January), high concentrations of desert dust from the Sahara and local biomass burning are advected into the region. Results presented here show that high levels of particulate matter are not confined to the local dry season but are present throughout much of the year as a result of long-range transport. This regional influx of aerosol presents a challenge for future management of air quality in countries across West Africa. Controlling air quality in these cities cannot be considered solely in terms of reducing local anthropogenic emissions. Rather, regional- and continental-scale sources of particulate matter, notably these large biomass burning sources, must be considered. This contrasts with air quality problems encountered in North America and Europe, where urban emissions contribute the majority of air pollution. Solely importing air quality strategies from these regions may therefore be unsuccessful in West Africa, given that transnational transport of particulate matter plays an important role. Thought should be given to changes in land use practices in countries across the African continent to reduce the quantity of biomass burning if human exposure to particulate matter is to be limited.

Data availability. Data from all three aircraft are publicly available on the SEDOO database (http://baobab.sedoo.fr/DACCIWA/; Coe and Taylor, 2017a, b; Evans and Lee, 2018; Sauer, 2017; Batenburg, 2019; Catoire, 2017; Schwarzenboeck and Dupuy, 2017; Brito, 2017; Brito and Dupuy, 2017; Perrin and Piguet, 2017; Ramonet et al., 2017).

Author contributions. SLH, JWT, JB, AMB, SB, JS, CS, CD, TB, $\mathrm{RD}, \mathrm{AS}, \mathrm{DS}, \mathrm{CF}, \mathrm{JD}$ and IC were involved in the collection, quality assurance and analysis of observational data used in this manuscript. ME, EM, BV and AD developed the model code and carried out simulations. SLH prepared the manuscript with significant contributions from all authors.

Competing interests. The authors declare that they have no conflict of interest.

Special issue statement. This article is part of the special issue "Results of the project 'Dynamics-aerosol-chemistry-cloud interactions in West Africa' (DACCIWA) (ACP/AMT inter-journal SI)". It is not associated with a conference.

Acknowledgements. The research leading to these results has received funding from the European Union Seventh Framework Programme (FP7/2007-2013) under grant agreement no. 603502. The lead author was supported by the Natural Environment Research Council Doctoral Training Programme (NERC DTP; grant no. NE/L002469/1). This paper contains modified Copernicus Atmosphere Monitoring Service Information 2018. The meteorological data used in this study have been provided by the Global Modeling and Assimilation Office (GMAO) at the NASA Goddard Space Flight Center. The participation of Anneke M. Batenburg, Christiane Schulz, Johannes Schneider and Stephan Borrmann on the DLR Falcon 20 in this campaign was made possible by internal funds of the Max Planck Institute for Chemistry in Mainz. We thank the British Antarctic Survey (BAS, operator of the Twin Otter), the Service des Avions Français Instrumentés pour la Recherche en Environnement (SAFIRE, a joint entity of CNRS, Météo-France and CNES and operator of the ATR-42), and the Deutsches Zentrum für Luft- und Raumfahrt (operator of the Falcon 20) for their support during the aircraft campaign. 
Financial support. This research has been supported by the Natural Environment Research Council (grant no. NE/L002469/1) and the FP7 Environment (DACCIWA (grant no. 603502)).

Review statement. This paper was edited by Federico Fierli and reviewed by two anonymous referees.

\section{References}

Adebiyi, A. A., Zuidema, P., and Abel, S. J.: The convolution of dynamics and moisture with the presence of shortwave absorbing aerosols over the Southeast Atlantic, J. Climate, 28, 1997-2024, https://doi.org/10.1175/Jcli-D-14-00352.1, 2015.

Allan, J. D., Delia, A. E., Coe, H., Bower, K. N., Alfarra, M., Jimenez, J. L., Middlebrook, A. M., Drewnick, F., Onasch, T. B., Canagaratna, M. R., Jayne, J. T., and Worsnop, D. R.: A generalised method for the extraction of chemically resolved mass spectra from Aerodyne aerosol mass spectrometer data, Aerosol Sci. Tech., 35, 909-922, https://doi.org/10.1016/j.jaerosci.2004.02.007, 2004.

Athanasopoulou, E., Rieger, D., Walter, C., Vogel, H., Karali, A., Hatzaki, M., Gerasopoulos, E., Vogel, B., Giannakopoulos, C., Gratsea, M., and Roussos, A.: Fire risk, atmospheric chemistry and radiative forcing assessment of wildfires in eastern Mediterranean, Atmos. Environ., 95, 113-125, https://doi.org/10.1016/j.atmosenv.2014.05.077, 2014.

Baldauf, M., Seifert, A., Förstner, J., Majewski, D., Raschendorfer, M., and Reinhardt, T.: Operational convective-scale numerical weather prediction with the COSMO model: description and sensitivities, Mon. Weather Rev., 139, 3887-3905, https://doi.org/10.1175/MWR-D-10-05013.1, 2011.

Bangert, M., Nenes, A., Vogel, B., Vogel, H., Barahona, D., Karydis, V. A., Kumar, P., Kottmeier, C., and Blahak, U.: Saharan dust event impacts on cloud formation and radiation over Western Europe, Atmos. Chem. Phys., 12, 4045-4063, https://doi.org/10.5194/acp-12-4045-2012, 2012.

Barbosa, P. M., Stroppiana, D., and Grégoire, J.-M.: An assessment of vegetation fire in Africa (1981-1991): burned areas, burned biomass, and atmospheric emissions, Global Biogeochem. Cy., 13, 933-950, https://doi.org/10.1029/1999GB900042, 1999.

Batenburg, A. M: Falcon MPI-C C-ToF-AMS, uploaded on 1 March 2019.

Bey, I., Jacob, D. J., Yantosca, R. M., Logan, J. A., Field, B. D., Fiore, A. M., Li, Q., Yiu, H. Y., Mickley, L. J., and Schultz, M. G.: Global modeling of tropospheric chemistry with assimilated meteorology: Model description and evaluation, J. Geophys. Res.-Atmos., 106, 23073-23095, https://doi.org/10.1029/2001JD000807, 2001.

Brito, J.: ATR Aerosol AMS, uploaded on 16 May 2017.

Brito, J. and Dupuy, R.: ATR Aerosol SMPS, uploaded on 16 May 2017.

Brito, J., Freney, E., Dominutti, P., Borbon, A., Haslett, S. L., Batenburg, A. M., Colomb, A., Dupuy, R., Denjean, C., Burnet, F., Bourriane, T., Deroubaix, A., Sellegri, K., Borrmann, S., Coe, H., Flamant, C., Knippertz, P., and Schwarzenboeck, A.: Assessing the role of anthropogenic and biogenic sources on $\mathrm{PM}_{1}$ over southern West Africa using aircraft measurements, Atmos.
Chem. Phys., 18, 757-772, https://doi.org/10.5194/acp-18-7572018, 2018.

Brocchi, V., Krysztofiak, G., Deroubaix, A., Stratmann, G., Sauer, D., Schlager, H., Deetz, K., Dayma, G., Robert, C., Chevrier, S., and Catoire, V.: Local air pollution from oil rig emissions observed during the airborne DACCIWA campaign, Atmos. Chem. Phys., 19, 11401-11411, https://doi.org/10.5194/acp-19-114012019, 2019.

Canagaratna, M. R., Jayne, J. T., Jimenez, J. L., Allan, J. D., Alfarra, M. R., Zhang, Q., Onasch, T. B., Drewnick, F., Coe, H., Middlebrook, A., Delia, A., Williams, L. R., Trimborn, A. M., Northway, M. J., DeCarlo, P. F., Kolb, C. E., Davidovits, P., and Worsnop, D. R.: Chemical and microphysical characterization of ambient aerosols with the Aerodyne Aerosol Mass Spectrometer, Mass Spectrom. Rev., 26, 185-222, https://doi.org/10.1002/mas.20115, 2007.

Capes, G., Johnson, B., McFiggans, G., Williams, P. I., Haywood, J., and Coe, H.: Aging of biomass burning aerosols over West Africa: aircraft measurements of chemical composition, microphysical properties, and emission ratios, J. Geophys. Res., 113 D23, https://doi.org/10.1029/2008JD009845, 2008.

Catoire, V.: Falcon-LPC2E-SpiritData-CO-NO2-V2, uploaded on 15 February 2017.

Chatfield, R. B., Vastano, J. A., Li, L., Sachse, G. W., and Connors, V. S.: The great African plume from biomass burning: generalizations from a three-dimensional study of TRACE A carbon monoxide, J. Geophys. Res., 103, 28059-28077, https://doi.org/10.1029/97JD03363, 1998.

Choi, Y., Rhee, T. S., Collette Jr., J. L., Taehyun, P., Park, S.-M., Seo, B.-K., Park, G., Park, K., and Lee, T.: Aerosol concentrations and composition in the North $\mathrm{Pa}-$ cific marine boundary layer, Atmos. Environ., 171, 165-172, https://doi.org/10.1016/j.atmosenv.2017.09.047, 2017.

Coe, H. and Taylor, J.: Twin Otter AMS, uploaded on 31 May 2017a.

Coe, H. and Taylor, J.: Twin Otter CPC, uploaded on 9 May 2017b.

Cubison, M. J., Ortega, A. M., Hayes, P. L., Farmer, D. K., Day, D., Lechner, M. J., Brune, W. H., Apel, E., Diskin, G. S., Fisher, J. A., Fuelberg, H. E., Hecobian, A., Knapp, D. J., Mikoviny, T., Riemer, D., Sachse, G. W., Sessions, W., Weber, R. J., Weinheimer, A. J., Wisthaler, A., and Jimenez, J. L.: Effects of aging on organic aerosol from open biomass burning smoke in aircraft and laboratory studies, Atmos. Chem. Phys., 11, 12049-12064, https://doi.org/10.5194/acp-11-12049-2011, 2011.

Das, S., Harshvardhan, H., Bian, H., Chin, M., Curci, G., Protonotariou, A. P., Mielonen, T., Zhang, K., Wang, H., and Liu, X.: Biomass burning aerosol transport and vertical distribution over the South African-Atlantic region, J. Geophys. Res., 122, 63916415, https://doi.org/10.1002/2016JD026421, 2017.

Deetz, K. and Vogel, B.: Development of a new gas-flaring emission dataset for southern West Africa, Geosci. Model Dev., 10, 1607 1620, https://doi.org/10.5194/gmd-10-1607-2017, 2017.

DeGouw, J. and Jimenez, J. L.: Organic aerosols in the Earth's atmosphere, Environ. Sci. Technol., 43, 7614-7618, https://doi.org/10.1021/es9006004, 2009.

Deroubaix, A., Flamant, C., Menut, L., Siour, G., Mailler, S., Turquety, S., Briant, R., Khvorostyanov, D., and Crumeyrolle, S.: Interactions of atmospheric gases and aerosols with the monsoon dynamics over the Sudano-Guinean region during AMMA, At- 
mos. Chem. Phys., 18, 445-465, https://doi.org/10.5194/acp-18445-2018, 2018.

Drewnick, F., Hings, S. S., DeCarlo, P. F., Jayne, J. T., Gonin, M., Fuhrer, K., Weimer, S., Jimenez, J. L., Demerjian, K. L., Borrmann, S., and Worsnop, D. R.: A new time-of-flight Aerosol Mass Spectrometer (ToF-AMS): instrument description and first field deployment, Aerosol Sci. Technol., 39, 637-658, https://doi.org/10.1080/02786820500182040, 2005.

Duong, H. T., Sorooshian, A., and Feingold, G.: Investigating potential biases in observed and modeled metrics of aerosol-cloudprecipitation interactions, Atmos. Chem. Phys., 11, 4027-4037, https://doi.org/10.5194/acp-11-4027-2011, 2011.

Edwards, D. P., Emmons, L. K., Gille, J. C., Chu, A., Attié, J.-L., Giglio, L., Wood, S. W., Haywood, J., Deeter, M. N., Massie, S. T., Ziskin, D. C., and Drummond, J. R.: Satellite-observed pollution from Southern Hemisphere biomass burning, J. Geophys. Res., 111, D14312, https://doi.org/10.1029/2005JD006655, 2006.

EC-JRC/PBL: Emission database for global atmospheric research (EDGAR), release version 4.2, European Commission, Joint Research Centre (JRC)/Netherlands Environmental Assessment Agency (PBL), available at: http://edgar.jrc.ec.europa.eu (last access: 31 October 2018), 2011.

Emmons, L. K., Walters, S., Hess, P. G., Lamarque, J.-F., Pfister, G. G., Fillmore, D., Granier, C., Guenther, A., Kinnison, D., Laepple, T., Orlando, J., Tie, X., Tyndall, G., Wiedinmyer, C., Baughcum, S. L., and Kloster, S.: Description and evaluation of the Model for Ozone and Related chemical Tracers, version 4 (MOZART-4), Geosci. Model Dev., 3, 43-67, https://doi.org/10.5194/gmd-3-43-2010, 2010.

Evans, M. and Lee, J.: Twin Otter In Situ Gas Data, uploaded on 15 January 2018.

Fitzgerald, J. W.: Marine aerosols: a review, Atmos. Environ., 25, 533-545, https://doi.org/10.1016/0960-1686(91)90050-H, 1991.

Flamant, C., Knippertz, P., Akpo, A., Brooks, B., Chiu, C., Coe, H., Danuor, S., Evans, M., Fink, A., Jegede, O., Kalthoff, N., Konaré, A., Liousse, C., Lohou, F., Mari, C., Schlager, H., Schwarzenboeck, A., Adler, B., Amekudzi, L., Aeyee, J., Ayoola, M., Batenburg, A., Bessardon, G., Bormann, S., Brito, J., Bower, K., Burne, F., Catoire, V., Colomb, A., Fossu-Amankwah, K., Hill, P., Lee, J., Lothon, M., Maranan, M., Marsham, J., Meynadier, R., Ngamini, J.-B., Rosenberg, P., Sauer, D., Smith, V., Stratmann, G., Taylor, J., Voigt, C., and Yoboué, V.: The DynamicsAerosol-Chemistry-Cloud Interactions in West Africa field campaigns: overview and research highlights, B. Am. Meteorol. Soc., 99, 83-104, https://doi.org/10.1175/BAMS-D-16-0256.1, 2018.

Gordon, H., Field, P. R., Abel, S. J., Dalvi, M., Grosvenor, D. P., Hill, A. A., Johnson, B. T., Miltenberger, A. K., Yoshioka, M., and Carslaw, K. S.: Large simulated radiative effects of smoke in the south-east Atlantic, Atmos. Chem. Phys., 18, 15261-15289, https://doi.org/10.5194/acp-18-15261-2018, 2018.

Guedje, F. K., Houeto, A. V. V., Houngninou, E. B., Fink, A. H., and Knippertz, P.: Climatology of coastal wind regimes in Benin, Meteorol. Z., 28, 24-49, https://doi.org/10.1127/metz/2019/0930, 2019.

Guenther, A. B., Jiang, X., Heald, C. L., Sakulyanontvittaya, T., Duhl, T., Emmons, L. K., and Wang, X.: The Model of Emissions of Gases and Aerosols from Nature version 2.1 (MEGAN2.1): an extended and updated framework for mod- eling biogenic emissions, Geosci. Model Dev., 5, 1471-1492, https://doi.org/10.5194/gmd-5-1471-2012, 2012.

Haslett, S. L., Taylor, J. W., Deetz, K., Vogel, B., Babić, K., Kalthoff, N., Wieser, A., Dione, C., Lohou, F., Brito, J., Dupuy, R., Schwarzenboeck, A., Zieger, P., and Coe, H.: The radiative impact of out-of-cloud aerosol hygroscopic growth during the summer monsoon in southern West Africa, Atmos. Chem. Phys., 19, 1505-1520, https://doi.org/10.5194/acp-191505-2019, 2019.

Hennigan, C. J., Miracolo, M. A., Engelhart, G. J., May, A. A., Presto, A. A., Lee, T., Sullivan, A. P., McMeeking, G. R., Coe, H., Wold, C. E., Hao, W.-M., Gilman, J. B., Kuster, W. C., de Gouw, J., Schichtel, B. A., Collett Jr., J. L., Kreidenweis, S. M., and Robinson, A. L.: Chemical and physical transformations of organic aerosol from the photo-oxidation of open biomass burning emissions in an environmental chamber, Atmos. Chem. Phys., 11, 7669-7686, https://doi.org/10.5194/acp11-7669-2011, 2011.

Hudman, R. C., Moore, N. E., Mebust, A. K., Martin, R. V., Russell, A. R., Valin, L. C., and Cohen, R. C.: Steps towards a mechanistic model of global soil nitric oxide emissions: implementation and space based-constraints, Atmos. Chem. Phys., 12, 7779-7795, https://doi.org/10.5194/acp-12-7779-2012, 2012.

Jolleys, M. D., Coe, H., McFiggans, G., Capes, G., Allan, J. D., Crosier, J., Williams, P. I., Allen, G., Bower, K. N., Jimenez, J. L., Russell, L. M., Grutter, M., and Baumgardner, D.: Characterizing the aging of biomass burning organic aerosol by use of mixing ratios: a meta-analysis of four regions, Environ. Sci. Technol., 46, 13093-13102, https://doi.org/10.1021/es302386v, 2012.

Junker, C. and Liousse, C.: A global emission inventory of carbonaceous aerosol from historic records of fossil fuel and biofuel consumption for the period 1860-1997, Atmos. Chem. Phys., 8, 1195-1207, https://doi.org/10.5194/acp-8-1195-2008, 2008.

Kaiser, J. W., Heil, A., Andreae, M. O., Benedetti, A., Chubarova, N., Jones, L., Morcrette, J.-J., Razinger, M., Schultz, M. G., Suttie, M., and van der Werf, G. R.: Biomass burning emissions estimated with a global fire assimilation system based on observed fire radiative power, Biogeosciences, 9, 527-554, https://doi.org/10.5194/bg-9-527-2012, 2012.

Kalthoff, N., Lohou, F., Brooks, B., Jegede, G., Adler, B., Babić, K., Dione, C., Ajao, A., Amekudzi, L. K., Aryee, J. N. A., Ayoola, M., Bessardon, G., Danuor, S. K., Handwerker, J., Kohler, M., Lothon, M., Pedruzo-Bagazgoitia, X., Smith, V., Sunmonu, L., Wieser, A., Fink, A. H., and Knippertz, P.: An overview of the diurnal cycle of the atmospheric boundary layer during the West African monsoon season: results from the 2016 observational campaign, Atmos. Chem. Phys., 18, 2913-2928, https://doi.org/10.5194/acp-18-2913-2018, 2018.

Kaufman, Y. J. and Fraser, R. S.: The effect of smoke particles on clouds and climate forcing, Science, 277, 1636-1639, https://doi.org/10.1126/science.277.5332.1636, 1997.

Kaufman, Y. J., Koren, I., Remer, L. A., Rosenfeld, D., and Rudich, Y.: The effect of smoke, dust, and pollution aerosol on shallow cloud development over the Atlantic Ocean, P. Natl. Acad. Sci. USA, 102, 11207-11212, https://doi.org/10.1073/pnas.0505191102, 2005.

Knippertz, P., Coe, H., Chiu, J. C., Evans, M. J., Find, A. H., Kalthoff, N., Liousse, C., Mari, C., Allan, R. P., Brooks, B., Danour, S., Flamant, C., Jegede, O. O., Lohou, F., and 
Marsham, J. H.: The DACCIWA project: Dynamics-AerosolChemistry-Cloud ineractions in West Africa, B. Am. Meteorol. Soc., 96, 1451-1460, https://doi.org/10.1175/BAMS-D-14$00108.1,2015$.

Knippertz, P., Fink, A. H., Deroubaix, A., Morris, E., Tocquer, F., Evans, M. J., Flamant, C., Gaetani, M., Lavaysse, C., Mari, C., Marsham, J. H., Meynadier, R., Affo-Dogo, A., Bahaga, T., Brosse, F., Deetz, K., Guebsi, R., Latifou, I., Maranan, M., Rosenberg, P. D., and Schlueter, A.: A meteorological and chemical overview of the DACCIWA field campaign in West Africa in June-July 2016, Atmos. Chem. Phys., 17, 10893-10918, https://doi.org/10.5194/acp-17-10893-2017, 2017.

Knote, C., Brunner, D., Vogel, H., Allan, J., Asmi, A., Äijälä, M., Carbone, S., van der Gon, H. D., Jimenez, J. L., Kiendler-Scharr, A., Mohr, C., Poulain, L., Prévôt, A. S. H., Swietlicki, E., and Vogel, B.: Towards an online-coupled chemistry-climate model: evaluation of trace gases and aerosols in COSMO-ART, Geosci. Model Dev., 4, 1077-1102, https://doi.org/10.5194/gmd-4-10772011, 2011.

Labonne, M., François-Marie, B., and Chevallier, F.: Injection height of biomass burning aerosols as seen from a spaceborne lidar, Geophys. Res. Lett., 34, L11806, https://doi.org/10.1029/2007GL029311, 2007.

Lamarque, J.-F., Bond, T. C., Eyring, V., Granier, C., Heil, A., Klimont, Z., Lee, D., Liousse, C., Mieville, A., Owen, B., Schultz, M. G., Shindell, D., Smith, S. J., Stehfest, E., Van Aardenne, J., Cooper, O. R., Kainuma, M., Mahowald, N., McConnell, J. R., Naik, V., Riahi, K., and van Vuuren, D. P.: Historical (1850-2000) gridded anthropogenic and biomass burning emissions of reactive gases and aerosols: methodology and application, Atmos. Chem. Phys., 10, 7017-7039, https://doi.org/10.5194/acp-10-7017-2010, 2010.

Lana, A., Bell, T. G., Simó, R., Vallina, S. M., Ballabrera-Poy, J., Kettle, A. J., Dachs, J., Bopp, L., Saltzman, E. S., Stefels, J., Johnson, J. E., and Liss, P. S.: An updated climatology of surface dimethlysulfide concentrations and emission fluxes in the global ocean, Global Biogeochem. Cy., 25, 1-17, https://doi.org/10.1029/2010GB003850, 2011.

Liousse, C., Assamoi, E., Criqui, P., Granier, C., and Rosset, R.: Explosive growth in African combustion emissions from 2005 to 2030, Environ. Res. Lett., 9, 035003, https://doi.org/10.1088/1748-9326/9/3/035003, 2014.

Lundgren, K., Vogel, B., Vogel, H., and Kottmeier, C.: Direct radiative effects of sea salt for the Mediterranean region under conditions of low to moderate wind speeds, J. Geophys. Res., 118, 1906-1923, https://doi.org/10.1029/2012JD018629, 2013.

Mari, C. H., Cailley, G., Corre, L., Saunois, M., Attié, J. L., Thouret, V., and Stohl, A.: Tracing biomass burning plumes from the Southern Hemisphere during the AMMA 2006 wet season experiment, Atmos. Chem. Phys., 8, 3951-3961, https://doi.org/10.5194/acp-8-3951-2008, 2008.

McComiskey, A. and Feingold, G.: Quantifying error in the radiative forcing of the first aerosol indirect effect, Geophys. Res. Lett., 35, L02810, https://doi.org/10.1029/2007GL032667, 2008.

Menut, L., Flamant, C., Turquety, S., Deroubaix, A., Chazette, P., and Meynadier, R.: Impact of biomass burning on pollutant surface concentrations in megacities of the Gulf of Guinea, Atmos. Chem. Phys., 18, 2687-2707, https://doi.org/10.5194/acp18-2687-2018, 2018.
Middlebrook, A. M., Bahreini, R., Jimenez, J. L., and Canagaratna, M. R.: Evaluation of composition-dependent collection efficiencies for the Aerodyne Aerosol Mass Spectrometer using field data, Aerosol Sci. Technol., 46, 258-271, 2012.

MOZART: MOZART-4/GEOS-5 forecasts, National Center for Atmospheric Research (NCAR), University Corporation for Atmospheric Research, Atmospheric Chemistry Observations and Modeling, available at: https://www.acom.ucar.edu/acresp/ AMADEUS/mz4_output/chemfcst/ (last access: 30 July 2017), 2017.

Murphy, J. G., Oram, D. E., and Reeves, C. E.: Measurements of volatile organic compounds over West Africa, Atmos. Chem. Phys., 10, 5281-5294, https://doi.org/10.5194/acp10-5281-2010, 2010.

Murray, L. T., Jacob, D. J., Logan, J. A., Hudman, R. C., and Koshak, W. J.: Optimized regional and interannual variability of lightning in a global chemical transport model constrained by LIS/OTD satellite data, J. Geophys. Res.-Atmos, 117, D20307, https://doi.org/10.1029/2012JD017934, 2012.

Ng, N. L., Canagaratna, M. R., Jimenez, J. L., Chhabra, P. S., Seinfeld, J. H., and Worsnop, D. R.: Changes in organic aerosol composition with aging inferred from aerosol mass spectra, Atmos. Chem. Phys., 11, 6465-6474, https://doi.org/10.5194/acp11-6465-2011, 2011.

Park, R. J., Jacob, D. J., Chin, M., and Martin, R. V.: Sources of carbonaceous aerosols over the United States and implications for natural visibility, J. Geophys. Res., 108, 4355, https://doi.org/10.1029/2002JD003190, 2003.

Peers, F., Bellouin, N., Waquet, F., Ducos, F., Goloub, P., Mollard, J., Myhre, G., Skeie, R. B., Takemura, T., Tanré, D., Thieuleux, F., and Zhang, K.: Comparison of aeorosl optical properties above clouds between POLDER nad AeroCom models over the South East Atlantic Ocean during the fire season, Geophys. Res. Lett., 43, 3991-4000, https://doi.org/10.1002/2016GL068222, 2016.

Perrin, T. and Piguet, B.: ATR Core instruments, uploaded on 8 June 2017

Phillips, V. T. J., DeMott, P. J., and Andronache, C.: An Empirical Parameterization of Heterogeneous Ice Nucleation for Multiple Chemical Species of Aerosol, J. Atmos. Sci., 65, 2757-2783, https://doi.org/10.1175/2007jas2546.1, 2008.

Ramanathan, V., Crutzen, P. J., Kiehl, J. T., and Rosenfeld, D.: Aerosols, climate, and the hydrological cycle, Science, 294, 2119-2124, https://doi.org/10.1126/science.1064034, 2001.

Ramonet, M., Piguet, B. and Hazan, L.: ATR GAS CO2, CH4, CO, uploaded on 12 October 2017.

Reeves, C. E., Formenti, P., Afif, C., Ancellet, G., Attié, J.-L., Bechara, J., Borbon, A., Cairo, F., Coe, H., Crumeyrolle, S., Fierli, F., Flamant, C., Gomes, L., Hamburger, T., Jambert, C., Law, K. S., Mari, C., Jones, R. L., Matsuki, A., Mead, M. I., Methven, J., Mills, G. P., Minikin, A., Murphy, J. G., Nielsen, J. K., Oram, D. E., Parker, D. J., Richter, A., Schlager, H., Schwarzenboeck, A., and Thouret, V.: Chemical and aerosol characterisation of the troposphere over West Africa during the monsoon period as part of AMMA, Atmos. Chem. Phys., 10, 7575-7601, https://doi.org/10.5194/acp-10-7575-2010, 2010.

Rieger, D., Bangert, M., Kottmeier, C., Vogel, H., and Vogel, B.: Impact of aerosol on post-frontal convective clouds over Germany, 
Tellus B, 66, 22528, https://doi.org/10.3402/tellusb.v66.22528, 2014.

Rieger, D., Steiner, A., Bachmann, V., Gasch, P., Förstner, J., Deetz, K., Vogel, B., and Vogel, H.: Impact of the 4 April 2014 Saharan dust outbreak on the photovoltaic power generation in Germany, Atmos. Chem. Phys., 17, 13391-13415, https://doi.org/10.5194/acp-17-13391-2017, 2017.

Sauer, D.: F20_CPC, uploaded on 27 October 2017.

Sauvage, B., Thouret, V., Cammas, J.-P., Gheusi, F., Athier, G., and Nédélec, P.: Tropospheric ozone over Equatorial Africa: regional aspects from the MOZAIC data, Atmos. Chem. Phys., 5, 311335, https://doi.org/10.5194/acp-5-311-2005, 2005.

Schrage, J. M. and Fink, A. H.: Nocturnal continental low-level stratus over tropical West Africa: observations and possible mechanisms controlling its onset, Mon. Weather Rev., 140, 1794-1809, https://doi.org/10.1175/MWR-D-11-00172.1, 2012.

Schwarzenboeck, A. and Dupuy, R.: ATR Aerosol CPC, uploaded on 2 May 2017.

Seifert, A. and Beheng, K. D.: A two-moment cloud microphysics parameterization for mixed-phase clouds, Part 1: Model description, Meteorol. Atmos. Phys., 92, 45-66, https://doi.org/10.1007/s00703-005-0112-4, 2006.

Stanelle, T., Vogel, B., Vogel, H., Bäumer, D., and Kottmeier, C.: Feedback between dust particles and atmospheric processes over West Africa during dust episodes in March 2006 and June 2007, Atmos. Chem. Phys., 10, 10771-10788, https://doi.org/10.5194/acp-10-10771-2010, 2010.

Taylor, J. W., Haslett, S. L., Bower, K., Flynn, M., Crawford, I., Dorsey, J., Choularton, T., Connolly, P. J., Hahn, V., Voigt, C., Sauer, D., Dupuy, R., Brito, J., Schwarzenboeck, A., Bourriane, T., Denjean, C., Rosenberg, P., Flamant, C., Lee, J. D., Vaughan, A. R., Hill, P. G., Brooks, B., Catoire, V., Knippertz, P., and Coe, H.: Aerosol influences on low-level clouds in the West African monsoon, Atmos. Chem. Phys., 19, 8503-8522, https://doi.org/10.5194/acp-19-8503-2019, 2019.

Terai, C. R., Wood, R., Leon, D. C., and Zuidema, P.: Does precipitation susceptibility vary with increasing cloud thickness in marine stratocumulus?, Atmos. Chem. Phys., 12, 4567-4583, https://doi.org/10.5194/acp-12-4567-2012, 2012.

Tiitta, P., Vakkari, V., Croteau, P., Beukes, J. P., van Zyl, P. G., Josipovic, M., Venter, A. D., Jaars, K., Pienaar, J. J., Ng, N. L., Canagaratna, M. R., Jayne, J. T., Kerminen, V.-M., Kokkola, H., Kulmala, M., Laaksonen, A., Worsnop, D. R., and Laakso, L.: Chemical composition, main sources and temporal variability of $\mathrm{PM}_{1}$ aerosols in southern African grassland, Atmos. Chem. Phys., 14, 1909-1927, https://doi.org/10.5194/acp-141909-2014, 2014.

Twomey, S.: The influence of pollution on the shortwave albedo of clouds, J. Atmos. Sci. 34, 1149-1152, https://doi.org/10.1175/15200469(1977)034<1149:TIOPOT>2.0.CO;2, 1977.

UN DESA: World population prospects: the 2017 revision, key findings \& advance tables, United Nations, Department of Economic and Social Affairs, Population Division, ESA/P/WP/248, 2017.

Vakkari, V., Kerminen, V.-M., Beukes, J. P., Tiitta, P., van Zyl, P. G., Josipovic, M., Venter, A. D., Jaars, K., Worsnop, D. R., Kulmala, M., and Laakso, L.: Rapid changes in biomass burning aerosols by atmospheric oxidation, Geophys. Res. Letters, 41, 2644-2651, https://doi.org/10.1002/2014GL059396, 2014.
Vogel, B., Vogel, H., Bäumer, D., Bangert, M., Lundgren, K., Rinke, R., and Stanelle, T.: The comprehensive model system COSMOART - Radiative impact of aerosol on the state of the atmosphere on the regional scale, Atmos. Chem. Phys., 9, 8661-8680, https://doi.org/10.5194/acp-9-8661-2009, 2009.

Voulgarakis, A., Marlier, M. E., Faluvegi, G., Shindell, D. T., Tsigaridis, K., and Mangeon, S.: Interannual variability of tropospheric trace gases and aerosols: the role of biomass burning emissions, J. Geophys. Res.-Atmos., 120, 7157-7173, https://doi.org/10.1002/2014JD022926, 2015.

Walter, C., Freitas, S. R., Kottmeier, C., Kraut, I., Rieger, D., Vogel, H., and Vogel, B.: The importance of plume rise on the concentrations and atmospheric impacts of biomass burning aerosol, Atmos. Chem. Phys., 16, 9201-9219, https://doi.org/10.5194/acp16-9201-2016, 2016.

Wang, C. and Prinn, R.: Impact of emissions, chemistry and climate on atmospheric carbon monoxide: 100 -yr predictions from a global chemistry-climate model, Chemosphere Global Change Sci., 1, 73-81, https://doi.org/10.1016/S1465-9972(99)00016-1, 1999.

Wang, Y. X., McElroy, M. B., Jacob, D. J., and Yantosca, R. M., A nested grid formulation for chemical transport over Asia: Applications to CO, J. Geophys. Res., 109, D22307, https://doi.org/10.1029/2004JD005237, 2004.

Weimer, M., Schröter, J., Eckstein, J., Deetz, K., Neumaier, M., Fischbeck, G., Hu, L., Millet, D. B., Rieger, D., Vogel, H., Vogel, B., Reddmann, T., Kirner, O., Ruhnke, R., and Braesicke, P.: An emission module for ICON-ART 2.0: implementation and simulations of acetone, Geosci. Model Dev., 10, 2471-2494, https://doi.org/10.5194/gmd-10-2471-2017, 2017.

Williams, P. I., McFiggans, G., and Gallagher, M. W.: Latitudinal aerosol size distribution variation in the Eastern Atlantic Ocean measured aboard the FS-Polarstern, Atmos. Chem. Phys., 7, 2563-2573, https://doi.org/10.5194/acp-7-2563-2007, 2007.

WHO: WHO air quality guidelines for particulate matter, ozone, nitrogen dioxide and sulfur dioxide: global update 2005, World Health Organisation, WHO/SDE/PHE/OEH/06.02, 2005.

Zängl, G., Reinert, D., Rípodas, P., and Baldauf, M.: The ICON (ICOsahedral Non-hydrostatic) modelling framework of DWD and MPI-M: Description of the non-hydrostatic dynamical core, Q. J. Roy. Meteorol. Soc., 141, 563-579, https://doi.org/10.1002/qj.2378, 2015.

Zhang, Q., Jimenez, J. L., Canagaratna, M. R., Ulbrich, I. M., Ng, N. L., Worsnop, D. R., and Sun, Y.: Understanding atmospheric organic aerosols via factor analysis of aerosol mass spectrometry: a review, Anal. Bioanal. Chem., 401, 3045-3067, https://doi.org/10.1007/s00216-011-5355-y, 2011.

Zuidema, P., Redeman, J., Haywood, J., Wood, R., Piketh, S., Hipondoka, M., and Formenti, P.: Smoke and clouds above the southeast Atlantic: upcoming field campaigns probe absorbing aerosol's impact on climate, B. Am. Meteorol. Soc., 97, 11311135, https://doi.org/10.1175/BAMS-D-15-00082.1, 2016.

Zuidema, P., Sedlacek III, A. J., Flynn, C., Springston, S., Delgadillo, R., Zhang, J., Aiken, A. C., Koontz, A., and Muradyan, P.: The Ascension Island boundary layer in the remote Southeast Atlantic is often smoky, Geophys. Res. Lett., 45, 9, 4456-4465, https://doi.org/10.1002/2017GL076926, 2018. 